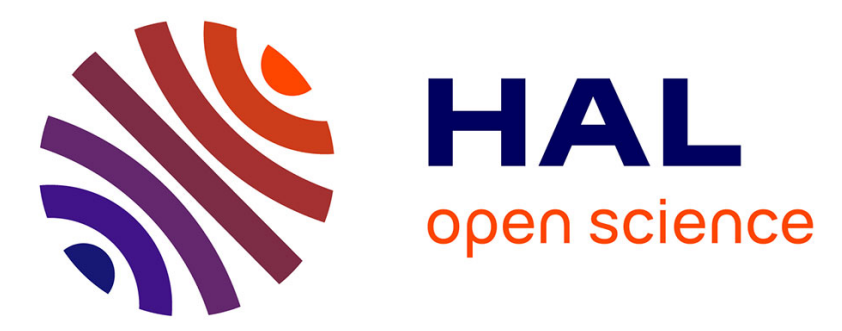

\title{
Late Cenozoic evolution of the central Longmen Shan, eastern Tibet: Insight from (U-Th)/He thermochronometry
}

Vincent Godard, R Pik, J Lavé, R Cattin, B Tibari, J de Sigoyer, M Pubellier, Jiamin Zhu

\section{To cite this version:}

Vincent Godard, R Pik, J Lavé, R Cattin, B Tibari, et al.. Late Cenozoic evolution of the central Longmen Shan, eastern Tibet: Insight from (U-Th)/He thermochronometry. Tectonics, 2009, 28 (5), 10.1029/2008TC002407 . hal-01577059

\section{HAL Id: hal-01577059 \\ https://hal-amu.archives-ouvertes.fr/hal-01577059}

Submitted on 24 Aug 2017

HAL is a multi-disciplinary open access archive for the deposit and dissemination of scientific research documents, whether they are published or not. The documents may come from teaching and research institutions in France or abroad, or from public or private research centers.
L'archive ouverte pluridisciplinaire HAL, est destinée au dépôt et à la diffusion de documents scientifiques de niveau recherche, publiés ou non, émanant des établissements d'enseignement et de recherche français ou étrangers, des laboratoires publics ou privés. 


\title{
Late Cenozoic evolution of the central Longmen Shan, eastern Tibet: Insight from (U-Th)/He thermochronometry
}

\author{
V. Godard, ${ }^{1,2}$ R. Pik, ${ }^{3}$ J. Lavé, ${ }^{3,4}$ R. Cattin,,${ }^{1,5}$ B. Tibari, ${ }^{3}$ J. de Sigoyer, ${ }^{1}$ M. Pubellier, ${ }^{1}$ \\ and J. Zhu ${ }^{6}$
}

Received 9 October 2008; revised 18 March 2009; accepted 6 July 2009; published 29 September 2009.

[1] This article presents (U-Th)/He thermochronological data from the Longmen Shan belt, eastern Tibet. Located between the Songpan-Garze terrane and the Yangtze craton, this mountain range is one of the steepest margins of the Tibetan Plateau and an important area for the comprehension of the mechanisms that control the dynamics of such plateau borders in terms of spatial distribution of deformation or timing of topographic building. We describe several age-elevation transects and perform forward modeling of our data to derive quantitative information on the exhumation of the range. A major phase of exhumation started at 8-11 Ma, with an average rate of $\sim 0.65 \mathrm{~mm} \mathrm{a}^{-1}$. Comparison of zircon and apatite ages indicates that the eastern part of the range may have experienced a significant decrease in exhumation since 2-3 Ma. We use the distribution of finite exhumation across the major faults of the area to quantify their dip-slip throw rate over the last $10 \mathrm{Ma}$. The Beichuan Fault, which was activated during the 2008 Sichuan earthquake, is the major active structure of the Longmen Shan since the late Miocene, with an average thrusting slip rate between 0.4 and $1 \mathrm{~mm} \mathrm{a}^{-1}$. Conversely, over the same time period, only minor dip-slip activity occurred on the Wenchuan Fault Zone. This distribution in space and time of exhumation and deformation is discussed and compared to the different proposed models for the geodynamical evolution of the eastern Tibetan margin. It also provides an important long-term perspective to put in context the destructive 2008 Sichuan earthquake that struck the central Longmen Shan.

\footnotetext{
${ }^{1}$ Laboratoire de Géologie, UMR 8538, Ecole Normale Supérieure, CNRS, Paris, France

${ }^{2}$ CEREGE, UMR 6635, Aix-Marseille Université, CNRS, Aix-enProvence, France.

${ }^{3}$ CRPG, UPR 2300, Nancy Université, CNRS, Vandoeuvre-Lès-Nancy, France.

${ }^{4}$ LGCA, UMR 5025, Université Joseph Fourier, CNRS, Saint-Martin d'Hères, France.

${ }^{5}$ Géosciences Montpellier, UMR 5243, Université Montpellier 2, CNRS, Montpellier, France.

${ }^{6}$ Chengdu University of Technology, Chengdu, China.

Copyright 2009 by the American Geophysical Union. 0278-7407/09/2008TC002407\$12.00
}

Citation: Godard, V., R. Pik, J. Lavé, R. Cattin, B. Tibari, J. de Sigoyer, M. Pubellier, and J. Zhu (2009), Late Cenozoic evolution of the central Longmen Shan, eastern Tibet: Insight from (U-Th)/He thermochronometry, Tectonics, 28, TC5009, doi:10.1029/ $2008 \mathrm{TC} 002407$.

\section{Introduction}

[2] The Tibetan Plateau is a major topographical expression of the ongoing collision between the Indian and Eurasian plates. It consists of a high-elevation and lowrelief surface that is thought to have been uplifted during the late Cenozoic, although the distribution of events in space and time is still debated [England and Houseman, 1989; Harrison et al., 1992; Tapponnier et al., 2001; Liu-Zeng et al., 2008]. The topographic transitions between the elevated and undissected surface of the plateau and the surrounding forelands define the margins, which focus active denudation processes due to high topographic gradients [Hodges, 2000; Lavé and Avouac, 2001; Kirby et al., 2003]. Documenting exhumation intensity, as well as its spatial and temporal variations is thus an important field of investigation to understand how those processes potentially control margin construction or degradation in relation with plateau building.

[3] The Longmen Shan range, which constitutes the eastern border of the Tibetan Plateau (Figure 1) is characterized by a steep topographic transition from the Sichuan Basin to the plateau but, in contrast with the Himalayas, no important shortening has been observed across the Longmen Shan from geodesy, at a timescale of $\sim 10$ years, prior to the May 2008 Sichuan earthquake [King et al., 1997; Chen et al., 2000]. Those observations lead to important questions on the nature of tectonic and denudation processes at work along this margin and their potential interactions. It also points out the Longmen Shan region as a critical target to test the geodynamical models proposed to describe the evolution of the region.

[4] In this article we address the question of the evolutionary mechanisms for this eastern margin of the Tibetan Plateau, using low temperature thermochronology. We first present new (U-Th)/He data, focused on the main faults of the central part of the Longmen Shan belt. Then, we interpret these new data with forward modeling of the ages to assess the evolution of exhumation conditions in this area. Finally, our results and interpretations are compared 

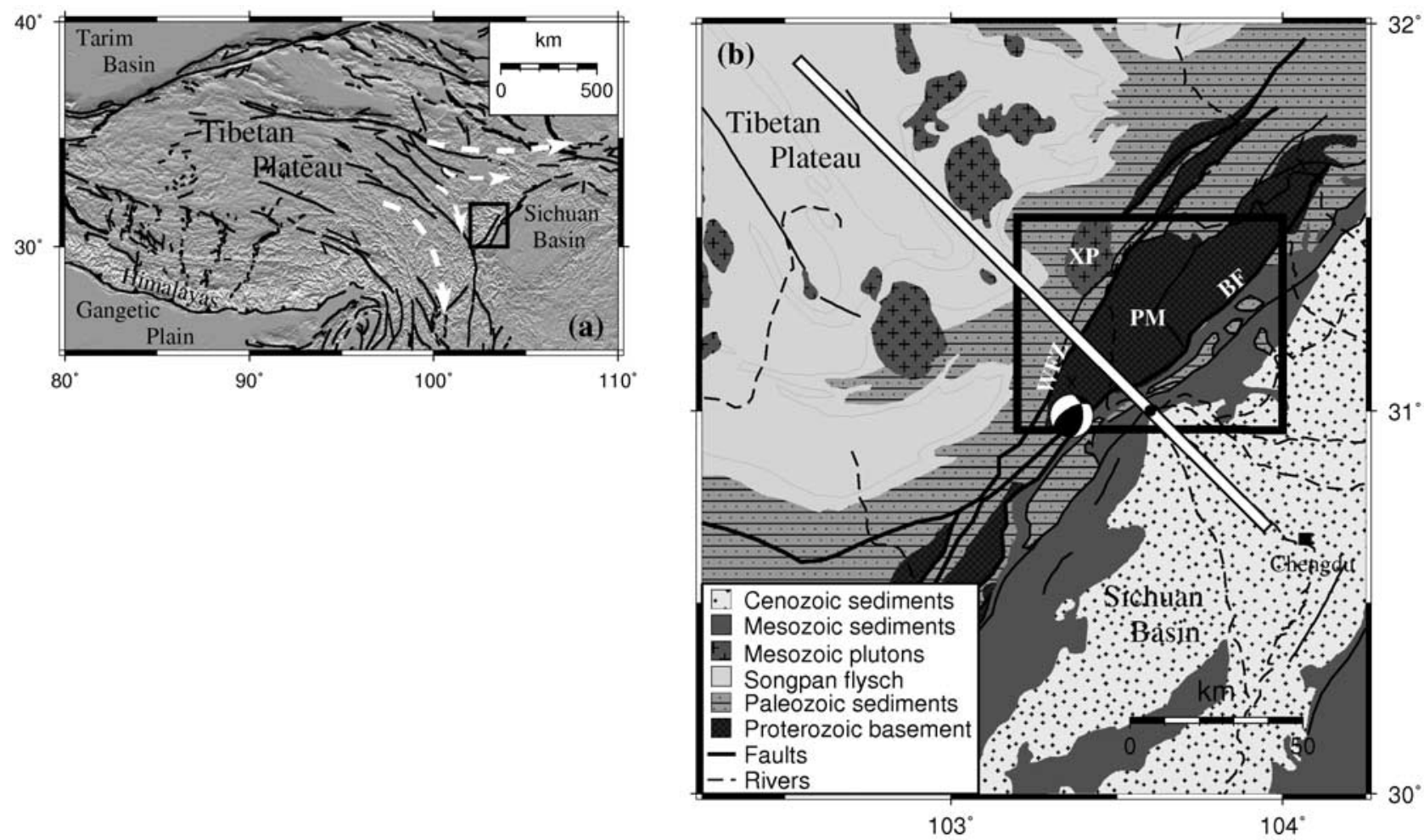

Figure 1. (a) Topographic map of the central and eastern Tibetan Plateau, with major tectonics features. The black box indicates the location of Figure 1b. The thick white arrows show the lower crustal flow directions proposed by Clark et al. [2005a]. (b) Situation map for the Longmen Shan with the main structural features of the area. The black box shows the location of Figure 3, and the white line indicates the position of the cross section from Figure 2. The focal mechanism for the 12 May 2008 eastern Sichuan earthquake is shown (USGS). PM, Pengguan Massif; XP, Xuelongbao Pluton; WFZ, Wenchuan Fault Zone; BF, Beichuan Fault.

with scenarios that have been proposed to explain the dynamics of this region.

\section{Geological Setting}

\subsection{Structure of the Longmen Shan Range}

[5] The Longmen Shan marks the transition between the low-elevation Sichuan basin $(\sim 500 \mathrm{~m})$ and the Tibetan Plateau $(\sim 4000 \mathrm{~m})$. It has a complex structure resulting from a multiphase history [Burchfiel et al., 1995; Chen et al., 1995; Burchfiel et al., 2008] and consists, from east to west, of the following tectonostratigraphic units.

[6] The foreland of the Longmen Shan is an important intracontinental basin (Sichuan Basin) presenting a thick Meso-Cenozoic continental detrital sedimentary series [Burchfiel et al., 1995]. Quaternary sedimentation is relatively scarce and discontinuous, which suggests no significant flexural loading of the present basin [Burchfiel et al., 1995; Royden et al., 1997]. The frontal units are made by the same lithofacies as the Sichuan Basin formations, and consist mainly in Triassic and Jurassic continental formations (shale and sandstone). Their structure is characterized by a thin-skinned fold and thrust deformation [Chen and Wilson, 1996].
[7] The highest part of the range is formed by a large basement core consisting of Proterozoic granitoids and metamorphic rocks of the Yangtze craton [Burchfiel et al., 1995; Chen and Wilson, 1996]. The Pengguan Massif (Figures 1 and 2) is the most prominent of those basement units. It is bounded on its eastern side by the Beichuan Fault (BF), which overthrusts the frontal Mesozoic formations described above, and on its western side by the Wenchuan Fault Zone (WFZ).

[8] Those basement blocks support an important platform sedimentary series, which was deposited during the Paleozoic when this part of the Yangtze craton was in passive margin configuration. Finally, Triassic turbidites deposited on the Paleozoic sediments, resulting in the thick flysch sequence of the Songpan Garze Fold Belt. This formation is affected by isoclinal folding and intruded by several granitic plutons, contemporary with the main Indosinian (late Triassic) deformation stage [Mattauer et al., 1992; Worley and Wilson, 1996; Roger et al., 2004; Harrowfield and Wilson, 2005].

\subsection{Cenozoic Tectonics and Exhumation}

[9] Deformation of the Longmen Shan during Cenozoic time is associated with the Himalayan orogenic cycle and 


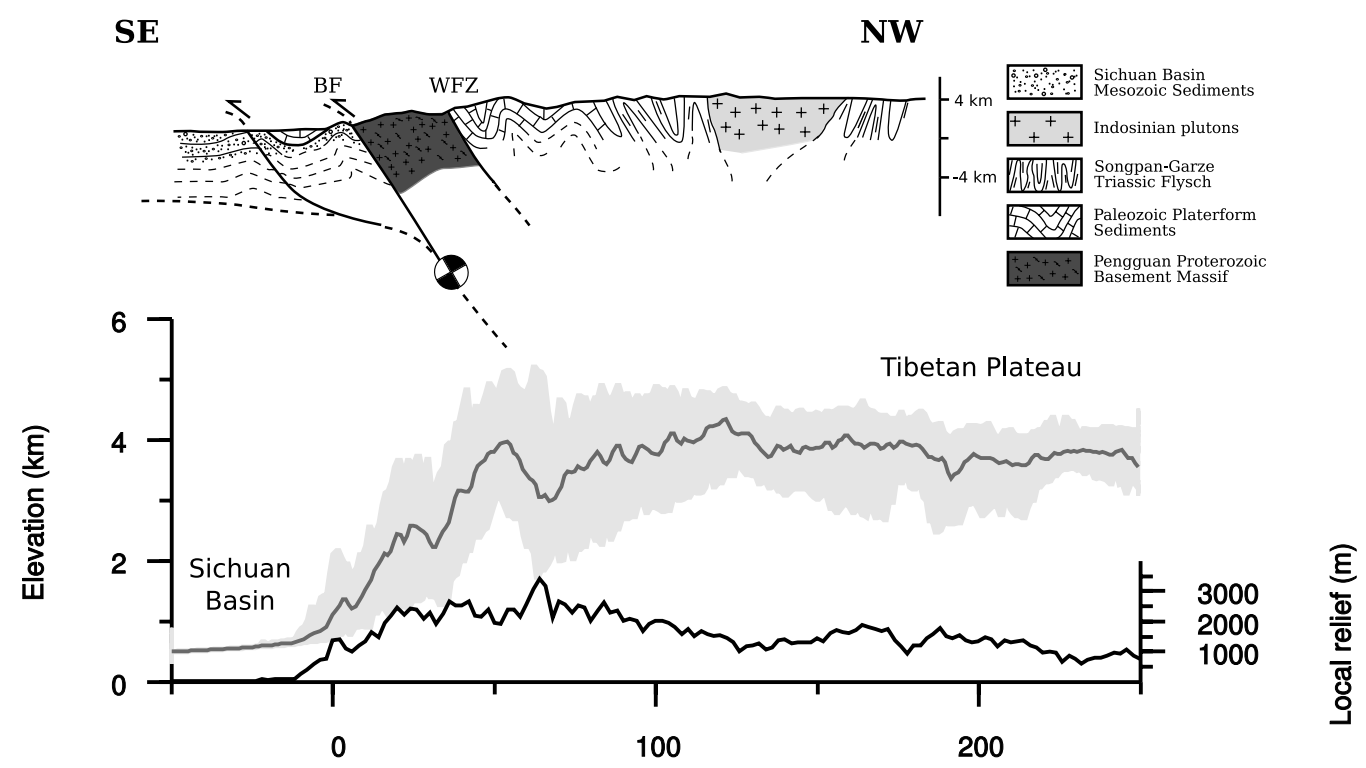

Horizontal distance $(\mathrm{km})$

Figure 2. Schematic geological cross section across the Central Longmen Shan, perpendicular to the strike of the range (adapted from Burchfiel et al. [1995], see position on Figure 1). The focal mechanism for the 12 May earthquake is indicated. Corresponding topography from GTOPO30 data set (mean and extreme values) and local relief profile. WFZ, Wenchuan Fault Zone; BF, Beichuan Fault.

Tibetan Plateau uplift. As stated above, markers of active tectonics are relatively rare in that region. Geodetic surveys do not indicate significant active convergence, with shortening velocities across the topographic step that are lower than $3 \mathrm{~mm} \mathrm{a}^{-1}$ and commonly lie below the confidence range of the measurement accuracy [King et al., 1997; Chen et al., 2000; Gan et al., 2007]. However, the May 2008 Sichuan thrusting earthquake has ruptured the BF for $\sim 200 \mathrm{~km}$ along strike, which suggests that slow stress accumulation occurs in the Longmen Shan.

[10] The nature and degree of activity along structures such as the WFZ and BF is debated and central to the proposed evolution models for this region [Densmore et al., 2007]. Arne et al. [1997] used fission track (FT) dating to show that the major faults of the margin could have been reactivated during the Cenozoic, with the India-Asia collision. Normal faulting activity across the WFZ is also proposed by several authors to accommodate differential exhumation between the plateau and the Longmen Shan [Meng et al., 2006; Burchfiel, 2004].

[11] At a regional scale, previous studies proposed a twostep exhumation scenario for this margin, which consists of a slow exhumation period during the Mesozoic and early Cenozoic, followed by the onset of rapid exhumation at the end of the Cenozoic [Arne et al., 1997; Kirby et al., 2002; Clark et al., 2005b]. From FT and Ar/Ar data, Arne et al. [1997] proposed a regional increase in cooling rate, and thus exhumation $\sim 20 \mathrm{Ma}$ ago. An important cooling event is also identified at that time by $X u$ and Kamp [2000], southwest of the Longmen Shan. Kirby et al. [2002] used (U-Th)/He and Ar/Ar dates to evaluate the exhumation rates for the two exhumation periods to $<0.1$ and $1-2 \mathrm{~mm} \mathrm{a}^{-1}$, respectively, and to propose a transition age ranging from 13 to $5 \mathrm{Ma}$. Finally, on the basis of (U-Th)/He and FT data in southeastern Tibet, $\sim 200 \mathrm{~km}$ south of the central Longmen Shan, Clark et al. [2005b] proposed that a recent denudation rate increase, at 9-13 $\mathrm{Ma}$, leads to values ranging between 0.25 and $0.5 \mathrm{~mm} \mathrm{a}^{-1}$.

[12] However, the nature of the exhumation mechanisms, the spatial extent and exact timing of the denudation increase in eastern Tibet, as well as the tectonic activity of the major faults in the Central Longmen Shan, are still poorly understood. In order to address these important questions and document the tectonic and denudational history of this particular Tibetan margin, we present new thermochronological data. To this purpose, we focused our study on sampling across major tectonic boundaries and on obtaining vertical sections to investigate age-elevation data. In that sense, our study is the first attempt to present such systematic age-elevation sampling across the Central Longmen Shan, which is essential for a detailed discussion of the exhumation history in this area.

\section{Sampling Strategy and Methods}

[13] We collected bedrock samples from various units in the Central Longmen Shan (Figure 3), in both the crystalline core of the range and in the frontal folds. In addition to several isolated samples, four vertical sampling transects were undertaken: one vertical transect from the Xuelongbao pluton [Worley and Wilson, 1996], located west of the WFZ (Figure 3), and three vertical transects from the Pengguan 


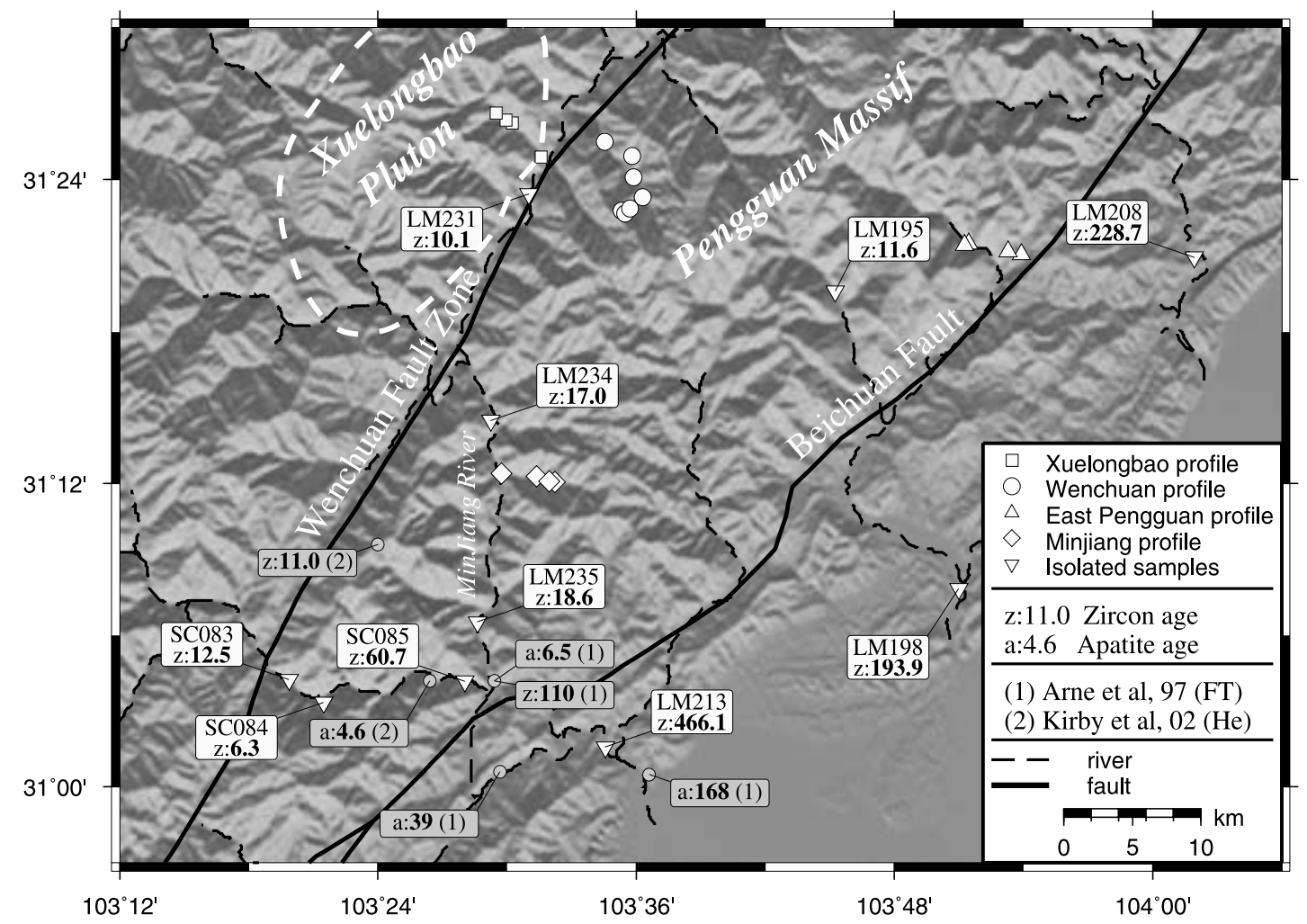

Figure 3. Location map of the age-elevation profiles and samples collected for zircon (U-Th)/He dating. Selected data from other studies are also presented (grey boxes), both fission track [Arne et al., 1997] and (U-Th)/He [Kirby et al., 2002], on both zircons and apatites. The Wenchuan and Beichuan faults bound the Pengguan Massif.

basement massif (see transect details and sample location in Table 1). The first and widest transect, or Wenchuan profile, is located on the east side of the WFZ, opposite to the Xuelongbao profile, and crosses the western flank of Pengguan Proterozoic basement massif. The second transect, or East Pengguan profile, is located on the eastern border of the Pengguan Massif, in the hanging wall of the Beichuan thrust fault (Figure 3), and will help to document the activity of this fault relative to the frontal Mesozoic folded detrital series of the Sichuan Basin. Finally, a fourth transect, or Min Jiang profile, was sampled along a small catchment in the Min Jiang river valley, to document exhumation inside the Pengguan Massif.

[14] Except for the frontal Mesozoic series, from which we sampled sandstones, all the other samples were collected in crystalline rocks. In the Pengguan Massif the dominant lithologies are diorite to granodiorite, whereas the Xuelongbao pluton presents more granitic compositions. Zircons are ubiquitous in the crystalline and sedimentary rocks we sampled. Apatites are in contrast generally rare, and suitable grains were found in only 5 samples among the 30 analyzed.

[15] For each sample, grains from 100 to $200 \mu \mathrm{m}$ fraction were carefully hand picked to select idiomorph and inclusion free specimens. Groups of $\sim 5$ zircon and $\sim 10$ apatite grains were loaded in small platinum tubes. Special care was taken to create homogeneous grain size groups, in order to be able to compute meaningful $\alpha$ ejection correction factors for the He ages [Ehlers and Farley, 2003]. The tubes were loaded in a resistance-heated furnace and grains were outgassed at $1000^{\circ} \mathrm{C}$ for apatite and $>1300^{\circ} \mathrm{C}$ for zircon. Extracted helium was expanded and purified in a dedicated line, and then directed to a noble gas spectrometer. After helium measurement the grains were retrieved from the furnace and $U$ and Th contents were measured by ICPMS [Pik et al., 2003]. The overall analytical uncertainty and precision on He ages for the whole process is estimated to be $\sim 6-8 \%$ [Kraml et al., 2006]. All measurements were conducted in the Centre de Recherches Pétrographiques et Géochimiques (CRPG) facilities.

\section{Results}

\subsection{Zircon Ages}

[16] Zircon He ages measured in the samples from the frontal folded sedimentary units range from 194 to $467 \mathrm{Ma}$. The deposition age of those samples is at most late Triassic (>230 Ma). Therefore, zircons probably present helium inheritance from earlier exhumation history, prior to their deposition in the Sichuan Basin. This suggests that they have not been buried deeper than the depth of the closure isotherm. 
Table 1. (U-Th)/He Zircons Data Obtained in This Study ${ }^{\mathrm{a}}$

\begin{tabular}{|c|c|c|c|c|c|c|c|c|c|c|c|}
\hline Sample & Latitude & Longitude & $\begin{array}{l}\text { Altitude } \\
\text { (m) }\end{array}$ & $\begin{array}{c}{ }^{4} \mathrm{He} \\
\left(\mathrm{nmol} \mathrm{g}^{-1}\right)\end{array}$ & $\begin{array}{c}\text { Th } \\
\text { (ppm) }\end{array}$ & $\begin{array}{c}\mathrm{U} \\
(\mathrm{ppm})\end{array}$ & $\begin{array}{l}\text { Length } \\
(\mu \mathrm{m})\end{array}$ & $\begin{array}{c}\text { Radius } \\
(\mu \mathrm{m})\end{array}$ & FT & $\begin{array}{c}\text { Raw Age } \\
\text { (Ma) }\end{array}$ & $\begin{array}{c}\text { Corrected Age } \\
\text { (Ma) }\end{array}$ \\
\hline \multicolumn{12}{|c|}{ Wenchuan Transect (Elevation Span $1500 \mathrm{~m}$, Horizontal Length $6 \mathrm{~km}$ ) } \\
\hline LM223 & 31.38859 & 103.60490 & 2474 & 189 & 3394.4 & 2105.6 & 177 & 132 & 0.82 & 12.0 & $14.6 \pm 1.2$ \\
\hline LM225 & 31.37965 & 103.58860 & 3185 & 65.6 & 925.0 & 720.0 & 180 & 128 & 0.82 & 13.0 & $15.8 \pm 1.3$ \\
\hline Rep & - & - & - & 51.0 & 1287.7 & 513.3 & 154 & 124 & 0.81 & 11.6 & $14.3 \pm 1.2$ \\
\hline LM226 & 31.37794 & 103.59114 & 3060 & 82.7 & 426.1 & 688.0 & 168 & 114 & 0.80 & 19.4 & $24.1 \pm 1.9$ \\
\hline Rep. & - & - & - & 55.6 & 291.7 & 508.3 & 174 & 106 & 0.80 & 17.8 & $22.4 \pm 1.8$ \\
\hline LM227 & 31.38123 & 103.59532 & 2806 & 64.4 & 400.0 & 521.4 & 154 & 110 & 0.79 & 19.4 & $24.4 \pm 2.0$ \\
\hline Rep & - & - & - & 97.8 & 506.7 & 666.7 & 168 & 108 & 0.80 & 23.0 & $28.9 \pm 2.3$ \\
\hline LM228 & 31.41541 & 103.59677 & 2232 & 86.5 & 2076.3 & 1650.0 & 273 & 166 & 0.87 & 7.5 & $8.7 \pm 0.7$ \\
\hline Rep & - & - & - & 93.9 & 1641.7 & 1966.7 & 190 & 102 & 0.79 & 7.4 & $9.3 \pm 0.8$ \\
\hline LM229 & 31.42490 & 103.57575 & 1731 & 18.2 & 75.0 & 156.3 & 201 & 90 & 0.78 & 19.4 & $25.0 \pm 2.0$ \\
\hline Rep & - & - & - & 41.7 & 321.7 & 443.5 & 172 & 88 & 0.76 & 14.9 & $19.5 \pm 1.6$ \\
\hline LM2196 & 31.40177 & 103.59813 & 2190 & 70.5 & 2929.4 & 1288.2 & 201 & 154 & 0.84 & 6.6 & $7.8 \pm 0.6$ \\
\hline \multicolumn{12}{|c|}{ Xuelongbao Transect (Elevation Span $900 \mathrm{~m}$, Horizontal Length $6 \mathrm{~km}$ ) } \\
\hline LM256 & 31.44363 & 103.49165 & 2330 & 6.8 & 76.8 & 93.8 & 233 & 120 & 0.82 & 11.2 & $13.7 \pm 1.1$ \\
\hline Rep & - & - & - & 5.92 & 59.2 & 104.8 & 250 & 119 & 0.83 & 9.2 & $11.2 \pm 0.9$ \\
\hline W1425 & 31.41486 & 103.52638 & 1439 & 27.9 & 292.7 & 655.9 & 295 & 132 & 0.84 & 7.1 & $8.4 \pm 0.7$ \\
\hline Rep & - & - & - & 30.6 & 499.8 & 591.4 & 226 & 115 & 0.82 & 8.0 & $9.8 \pm 0.8$ \\
\hline W1848 & 31.43891 & 103.49891 & 1860 & 8.5 & 142.2 & 264.6 & 211 & 104 & 0.80 & 5.3 & $6.6 \pm 0.5$ \\
\hline Rep & - & - & - & 7.8 & 101.5 & 189.6 & 278 & 108 & 0.82 & 6.8 & $8.3 \pm 0.7$ \\
\hline W2093 & 31.43733 & 103.50397 & 1956 & 19.7 & 471.4 & 391.1 & 229 & 114 & 0.81 & 7.3 & $8.9 \pm 0.7$ \\
\hline Rep & - & - & - & 12.2 & 158.4 & 298.6 & 250 & 110 & 0.82 & 6.7 & $8.2 \pm 0.7$ \\
\hline W2130 & 31.43871 & 103.50224 & 2130 & 9.3 & 90.1 & 169.2 & 244 & 116 & 0.82 & 9.1 & $11.1 \pm 0.9$ \\
\hline \multicolumn{12}{|c|}{ East Pengguan Transect (Elevation Span $350 \mathrm{~m}$, Horizontal Length $5 \mathrm{~km}$ ) } \\
\hline SC062 & 31.35100 & 103.89813 & 1726 & 65.7 & 220.3 & 1600.0 & 211 & 109 & 0.81 & 7.4 & $9.1 \pm 0.7$ \\
\hline SC064 & 31.35802 & 103.85751 & 2061 & 54.8 & 291.1 & 563.4 & 289 & 105 & 0.81 & 16.1 & $19.8 \pm 1.6$ \\
\hline $\mathrm{SC} 065$ & 31.35678 & 103.85421 & 1927 & 83.4 & 826.8 & 1313.5 & 221 & 96 & 0.79 & 10.2 & $13.0 \pm 1.0$ \\
\hline SC067 & 31.35292 & 103.88783 & 1807 & 76.5 & 262.6 & 1444.9 & 173 & 83 & 0.76 & 9.4 & $12.4 \pm 1.0$ \\
\hline \multicolumn{12}{|c|}{ Min Jiang Transect (Elevation Span $700 \mathrm{~m}$, Horizontal Length $4 \mathrm{~km}$ ) } \\
\hline SC074 & 31.20100 & 103.53700 & 1755 & 23.6 & 118.8 & 219.7 & 302 & 148 & 0.86 & 17.7 & $20.6 \pm 1.7$ \\
\hline SC077 & 31.20137 & 103.53246 & 1526 & 1327.5 & 10005.7 & 40862.6 & 200 & 80 & 0.76 & 5.7 & $7.5 \pm 0.6$ \\
\hline SC079 & 31.20452 & 103.52268 & 1350 & 9.0 & 419.4 & 558.3 & 282 & 90 & 0.79 & 2.5 & $3.2 \pm 0.3$ \\
\hline Rep & - & - & - & 11.8 & 110.9 & 303.2 & 242 & 86 & 0.78 & 6.7 & $8.6 \pm 0.7$ \\
\hline SC081 & 31.20668 & 103.49553 & 1056 & 16.8 & 191.6 & 324.2 & 234 & 147 & 0.85 & 8.4 & $9.9 \pm 0.8$ \\
\hline \multicolumn{12}{|c|}{ Other Samples } \\
\hline LM195 & 31.32680 & 103.75413 & 1495 & 22.6 & 118.4 & 405.3 & 244 & 128 & 0.84 & 9.7 & $11.6 \pm 0.9$ \\
\hline LM231 & 31.39070 & 103.51685 & 1295 & 7.3 & 78.3 & 156.5 & 146 & 92 & 0.77 & 7.7 & $10.1 \pm 0.8$ \\
\hline LM234 & 31.24152 & 103.48702 & 1130 & 54.5 & 442.1 & 621.1 & 209 & 119 & 0.82 & 13.9 & $17.0 \pm 1.4$ \\
\hline LM235 & 31.10891 & 103.47675 & 930 & 39.1 & 186.2 & 420.7 & 206 & 139 & 0.84 & 15.6 & $18.6 \pm 1.5$ \\
\hline Rep & - & - & - & 57.2 & 282.8 & 620.7 & 197 & 132 & 0.83 & 15.4 & $18.6 \pm 1.5$ \\
\hline SC083 & 31.07087 & 103.33098 & 1452 & 8.8 & 88.8 & 143.9 & 95 & 207 & 0.79 & 9.9 & $12.5 \pm 1.0$ \\
\hline SC084 & 31.05577 & 103.35773 & 1712 & 10.0 & 283.9 & 350.2 & 167 & 65 & 0.70 & 4.4 & $6.3 \pm 0.5$ \\
\hline SC085 & 31.06971 & 103.46723 & 939 & 36.3 & 93.1 & 118.4 & 203 & 97 & 0.79 & 47.8 & $60.7 \pm 4.9$ \\
\hline \multicolumn{12}{|c|}{ Detrital Units (Late Triassic) } \\
\hline LM198 & 31.13081 & 103.84963 & 811 & 103.2 & 26.9 & 113.7 & 220 & 109 & 0.81 & 157.3 & $193.9 \pm 15.5$ \\
\hline LM208 & 31.34893 & 104.03228 & 794 & 375.8 & 173.8 & 329.4 & 250 & 106 & 0.81 & 185.2 & $228.7 \pm 18.3$ \\
\hline LM213 & 31.02638 & 103.57574 & 762 & 516.3 & 75.7 & 231.7 & 232 & 98 & 0.80 & 371.1 & $466.1 \pm 37.3$ \\
\hline
\end{tabular}

${ }^{a}$ Reported uncertainties on cooling ages are $2 \sigma$, based on a $8 \%$ analytical precision [Kraml et al., 2006]. The computation of $\alpha$ ejection factor FT for the correction of the ages is made by calculating the surface/volume ratio of the parallelepipedic grains and using the factors proposed by Hourigan et al. [2005]. Rep denotes replicate sample. For each sample, $5 \pm 1$ zircon grains were loaded.

[17] To the contrary, zircon He ages measured inside the crystalline core of the Central Longmen Shan, in the vicinity of the Wenchuan and Beichuan faults, range from 29 to 6-7 Ma (Table 1, except for two singular ages of 3 and $60 \mathrm{Ma}$ ). Those young Miocene $\mathrm{He}$ ages from the inner part of the Longmen Shan, suggest that erosion along the margin exhumed zircons buried deeper in the crust, close to, or below the closure temperature. Most of these samples have been collected along vertical transects over $\sim 6 \mathrm{~km}$ of horizontal distance, with a typical change in elevation of $\sim 1 \mathrm{~km}$. Analytical formulations for the thermal structure below the topography indicate that, at these length scales, the deflection of the zircon helium partial retention zone (PRZ) is $\sim 100 \mathrm{~m}$ [Braun et al., 2006]. Hence, we consider that it is reasonable to regard our transects as vertical exhumed crustal sections.

[18] Samples from the higher elevation Wenchuan transect display a wide age span (7-30 Ma) and a general shallow slope trend in the age-elevation plot (Figure 4), except for the lowermost sample (LM229) which does not follow the general trend. We note that we cannot propose a unique trend, mainly due to the existence of a relatively 


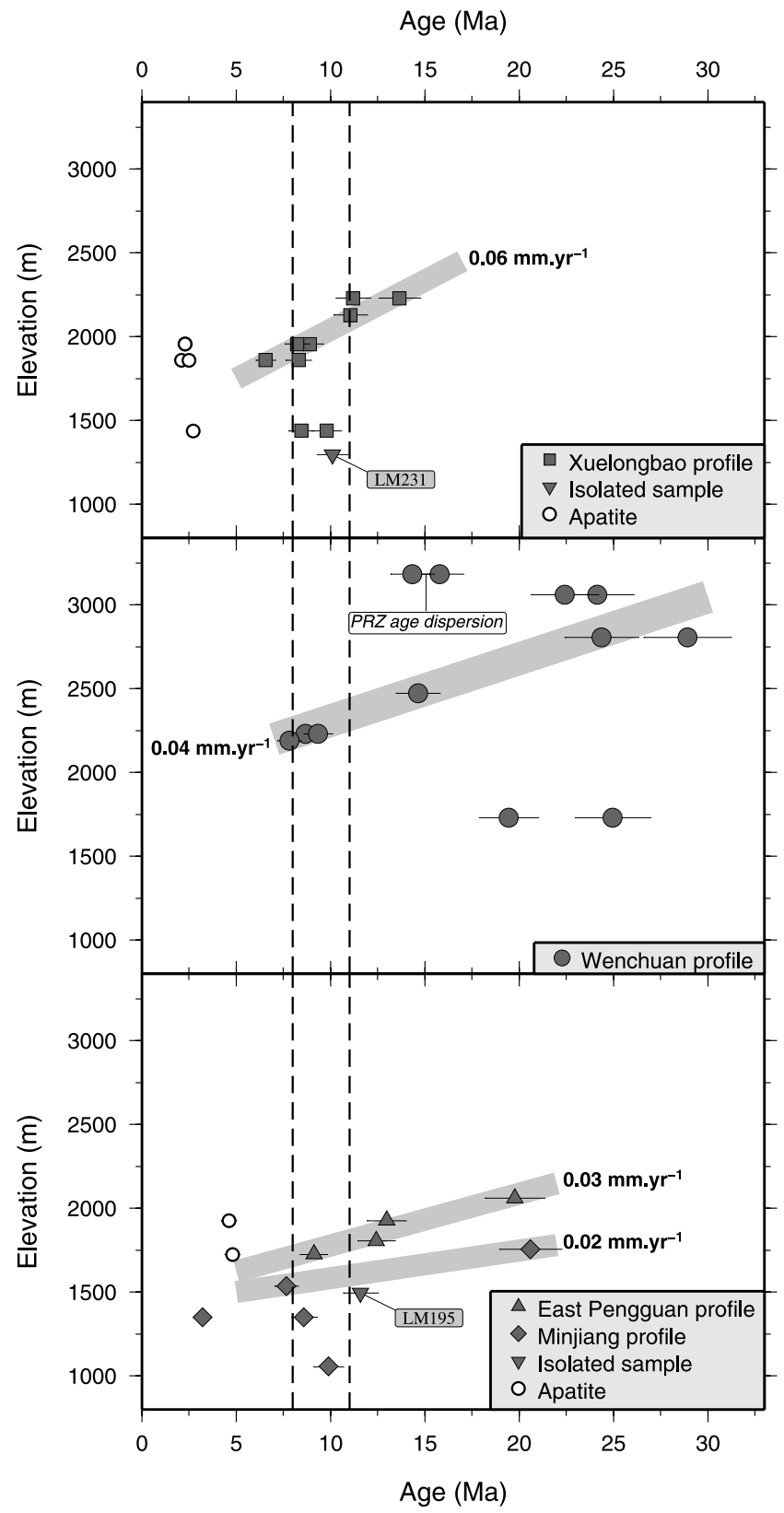

Figure 4. Age-elevation transects collected in the Central Longmen Shan (see Figure 3 for the location of the samples and Tables 1 and 2). Each inset focuses on a subset of the data. The thick light grey lines indicate potential trends in the upper part of the data sets, corresponding to the slow exhumation period. Vertical dashed lines limit the 8-11 Ma range corresponding to the onset of high exhumation inferred from modelings of Figure 8. Some isolated samples that are close to the profiles are also plotted.

young age at the top of the transect (sample LM225). However, this part of the data set can still be characterized by a wide spread of the ages within a relatively narrow elevation span. On the other side of the WFZ, the uppermost samples of the Xuelongbao transect range in age between 7 and $12 \mathrm{Ma}$ and also presents a shallow slope trend (Figure 4), compatible with the base of the Wenchuan transect pattern having been offset by a small amount of $\sim 200 \mathrm{~m}$. The East Pengguan transect, just west of the BF, also displays a wide range of ages from 9 to 20 Ma related by a shallow trend slope, but exhibits a more important altitudinal offset than the westernmost transects.

[19] For all these high-elevation samples $(>1500 \mathrm{~m})$ the common age-elevation relationship allows to infer very low apparent exhumation rates which can be attributed to slow cooling through the PRZ. Those rocks have resided for a long time inside the PRZ and, consequently, small variations in grain size, fluid circulation, homogeneity of the temperature field or topography, from a sample to another, can result in important differences in the apparent age, which may explain the position of samples such as LM225.

[20] On the other hand, all other samples taken below the altitude of $\sim 1500 \mathrm{~m}$ (Figure 4) display younger ages (7$10 \mathrm{Ma}$ ) with a relatively narrow distribution, and do not present significant dependence with elevation. This is the case for the lower part of the Xuelongbao transect, as well as sample LM231 collected a few kilometers downstream on the Min Jiang river, for most samples from the Min Jiang profile, and also for other isolated samples taken in the Pengguan Massif (Figure 4). This pool of younger ages outcropping below a zone of older and spatially more scattered ages, suggests a rapid cooling at the time ( $\sim 10 \mathrm{Ma})$ they crossed the PRZ.

\subsection{Apatite Ages}

[21] Apatites ages were obtained for five samples (Table 2) and are significantly younger $(2-5 \mathrm{Ma})$ than zircon ages. Along the Xuelongbao transect three samples present consistent ages of $\sim 2.5 \mathrm{Ma}$ and $\sim 8-9 \mathrm{Ma}$ on apatite and zircon, respectively. Assuming closure temperatures for zircon and apatite of $180^{\circ} \mathrm{C}$ and $60^{\circ} \mathrm{C}$, respectively [Reiners, 2005; Farley, 2000], and a surface temperature of $15^{\circ} \mathrm{C}$, a simple calculation gives a cooling rate of $18^{\circ} \mathrm{Ma}^{-1}$ from 0 to $2.5 \mathrm{Ma}$ and $20^{\circ} \mathrm{Ma}^{-1}$ from 2.5 to $8.5 \mathrm{Ma}$. This would suggest that the exhumation was relatively constant during the recent active phase across Xuelongbao area. In contrast, older ages of $\sim 4$ Ma characterize the East Pengguan profile despite relatively similar zircon He ages. This leads to a cooling rate of $\sim 11^{\circ} \mathrm{Ma}^{-1}$ and suggests that this region could have therefore experienced a recent decrease of the exhumation rate.

\section{Quantitative Analysis of Zircon Ages}

\subsection{Modeling Strategy}

[22] On the basis of the first interpretations presented above we develop models in order to extract quantitative information from our zircon age-elevation transects. Indeed, the ages are dependent on the thermal history of the samples. Because variations in the exhumation conditions affect the geotherm, they also control helium diffusion out of the mineral grains [Reiners and Brandon, 2006]. For that reason it is necessary to explicitly model both the thermal 
Table 2. (U-Th)/He Apatite Data Obtained in This Study ${ }^{\mathrm{a}}$

\begin{tabular}{|c|c|c|c|c|c|c|c|c|c|c|c|}
\hline Sample & Latitude & Longitude & $\begin{array}{l}\text { Altitude } \\
\text { (m) }\end{array}$ & $\begin{array}{c}{ }^{4} \mathrm{He} \\
\left(\mathrm{nmol} \mathrm{g}^{-1}\right)\end{array}$ & $\begin{array}{c}\text { Th } \\
(\mathrm{ppm})\end{array}$ & $\begin{array}{c}\mathrm{U} \\
(\mathrm{ppm})\end{array}$ & $\begin{array}{l}\text { Length } \\
(\mu \mathrm{m})\end{array}$ & $\begin{array}{c}\text { Radius } \\
(\mu \mathrm{m})\end{array}$ & FT & $\begin{array}{c}\text { Raw Age } \\
\text { (Ma) }\end{array}$ & $\begin{array}{c}\text { Corrected Age } \\
\text { (Ma) }\end{array}$ \\
\hline \multicolumn{12}{|c|}{ Xuelongbao Transect } \\
\hline W1425 & 31.41486 & 103.52638 & 1439 & 0.4 & 58.3 & 19.8 & 166 & 116 & 0.80 & 2.2 & $2.7 \pm 0.2$ \\
\hline W1848 & 31.43891 & 103.49891 & 1860 & 0.6 & 11.1 & 62.8 & 251 & 145 & 0.85 & 1.8 & $2.1 \pm 0.2$ \\
\hline Rep. & - & - & - & 0.8 & 20.3 & 70.2 & 186 & 105 & 0.80 & 2.0 & $2.5 \pm 0.2$ \\
\hline W2093 & 31.43733 & 103.50397 & 1956 & 1.9 & 95.2 & 165.6 & 248 & 120 & 0.83 & 1.9 & $2.3 \pm 0.2$ \\
\hline Rep. & - & - & - & 1.7 & 88.6 & 141.2 & 234 & 122 & 0.83 & 1.9 & $2.3 \pm 0.2$ \\
\hline \multicolumn{12}{|c|}{ East Pengguan Transect } \\
\hline $\mathrm{SC} 062$ & 31.35100 & 103.89813 & 1726 & 1.0 & 41.5 & 36.3 & 196 & 133 & 0.83 & 4.0 & $4.8 \pm 0.4$ \\
\hline SC065 & 31.35678 & 103.85421 & 1927 & 0.9 & 63.4 & 31.8 & 203 & 115 & 0.81 & 3.7 & $4.6 \pm 0.4$ \\
\hline
\end{tabular}

${ }^{\mathrm{a}}$ For each sample, $10 \pm 2$ apatite grains were loaded.

structure associated with exhumation and the helium diffusion in a combined approach [e.g., Braun and Robert, 2005; Kirstein et al., 2006; Whipp et al., 2007].

\subsubsection{Numerical Methods}

[23] We solve the following transient heat equation, using a Crank-Nicolson 1-D implicit scheme, in order to quantify the evolution of temperature $T$ as a function of time $t$ and vertical coordinate $z$,

$$
\rho C_{p}\left(\frac{\partial T}{\partial t}+v_{z} \frac{\partial T}{\partial z}\right)=k \frac{\partial^{2} T}{\partial z^{2}}+H
$$

where $\rho$ is the density, $C_{p}$ is the heat capacity, $k$ is the thermal conductivity, $T$ is the temperature, and $H$ is the radiogenic heat production. Temperature values at the surface and at the bottom of the model (Moho) are fixed to $T_{s}$ and $T_{m}$, respectively, and we use a steady state geotherm to initiate the computation. We account for vertical advection $v_{z}$ associated with exhumation by solving the equation on a moving grid. We do not introduce horizontal heat advection that could be due to tectonic shortening. The stability and accuracy of our numerical solutions were validated by comparison to an analytical formulation, for various exhumation regimes [Godard, 2006].

[24] To estimate the effect of the thermal conditions in the crust, we use three sets of thermal parameters for the properties of crustal materials (Table 3 ). Those three sets of parameters encompass the range of observed values in our working area and define three geotherms, consisting in a

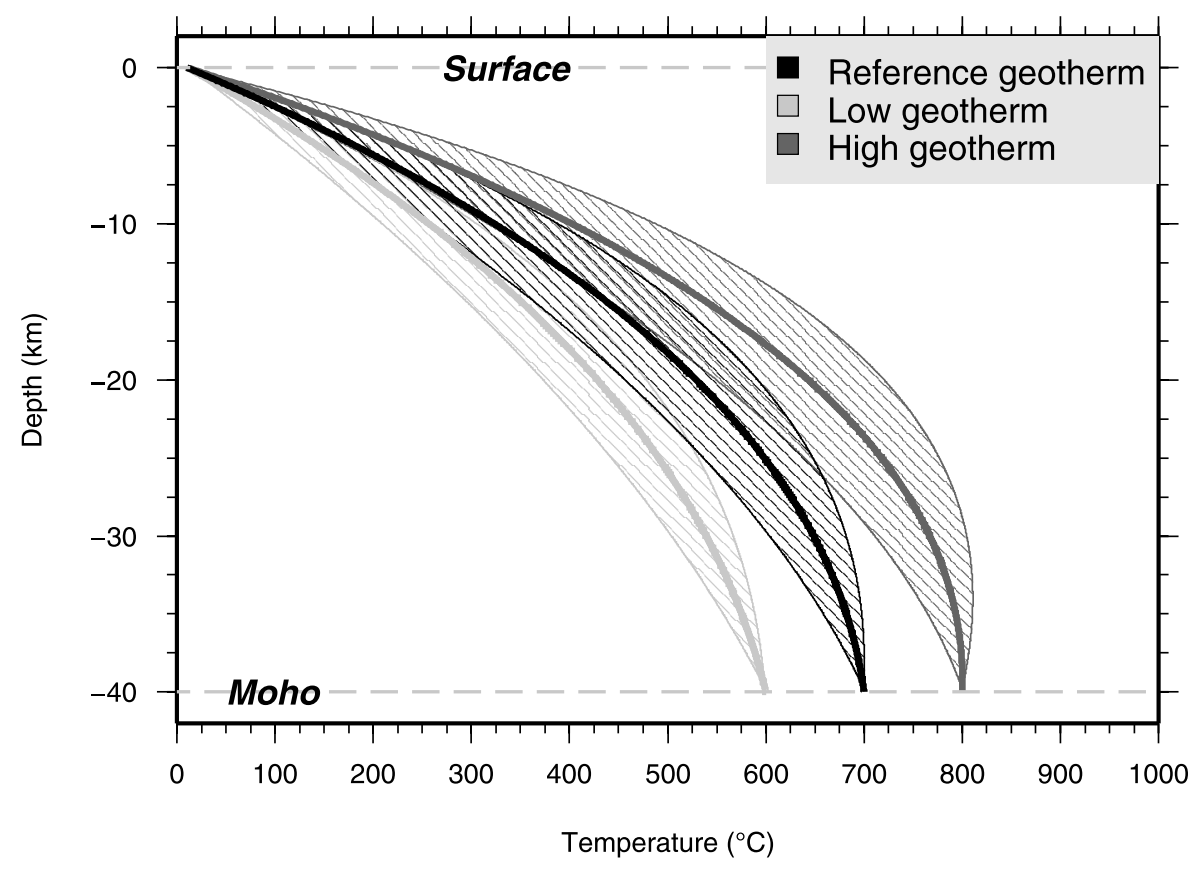

Figure 5. Steady crustal geotherms associated with the three sets of thermal parameters used in this study (Table 3). For each set of parameters the envelope indicates to the $0-1 \mathrm{~mm} \mathrm{a}^{-1}$ range for exhumation values. The solid line corresponds to an exhumation rate of $0.5 \mathrm{~mm} \mathrm{a}^{-1}$. 
Table 3. Thermal Properties of Crustal Materials Used for the Resolution of the Geotherm ${ }^{\mathrm{a}}$

\begin{tabular}{|c|c|c|c|c|c|}
\hline & Low & Reference & High & Reported & References \\
\hline \multicolumn{6}{|c|}{ Input Values } \\
\hline Conductivity $\left(\mathrm{W} \mathrm{m}^{-1} \mathrm{~K}^{-1}\right)$ & 2.25 & 2. & 1.75 & $2.03-4.0^{\mathrm{b}}$ & Zhou et al. [2000] \\
\hline Capacity $\left(\mathrm{J} \mathrm{kg}^{-1} \mathrm{~K}^{-1}\right)$ & - & 1000. & - & & \\
\hline Density & - & 2.8 & - & & \\
\hline Heat production $\left(10^{-6} \mathrm{~W} \mathrm{~m}^{-3}\right)$ & 0.75 & 1. & 1.25 & $0.56-5.09^{\mathrm{b}}$ & Wang et al. [2000] \\
\hline Crustal thickness (km) & - & 40 & - & $35-45^{\mathrm{b}}$ & Jiang and Jin [2005] \\
\hline Surface temperature $\left({ }^{\circ} \mathrm{C}\right)$ & - & 10 & - & & \\
\hline Moho temperature $\left({ }^{\circ} \mathrm{C}\right)$ & 600 & 700 & 800 & $550-820^{\mathrm{b}}$ & Wang et al. [2000] \\
\hline Surface heat flow $\left(\mathrm{mW} \mathrm{m}^{-2}\right)$ & $48-65-85$ & $54-75-99$ & $60-84-114$ & $76 \pm 13^{\mathrm{c}}$ & Hu et al. [2000] \\
\hline
\end{tabular}

${ }^{a}$ Equation (1). The three values for the surface heat flow refers to three different exhumation rates, $0,0.5$, and $1 . \mathrm{mm} \mathrm{a}^{-1}$, respectively. Reported values in the literature for several parameters are also indicated.

${ }^{\mathrm{b}}$ Values represent reported ranges in the Sichuan Basin and Longmen Shan.

${ }^{\mathrm{c}}$ This value is the mean regional heat flow $( \pm 1 \sigma)$.

reference geotherm, a high and a low assumption (Figure 5). Our approach does not take into account the influence of groundwater flow on the heat transport. Such processes are difficult to quantify in our working area. This approximation implies (1) that our computation provides minimal values for the geotherm, (2) that the calculated ages are upper bounds, and (3) that the inferred exhumation rates are minimal values.

[25] Our calculation of the ages is based on the transient diffusion of Helium inside spherical grains [Wolf et al., 1998]. We use a Crank-Nicolson 1-D implicit scheme to solve

$$
\frac{\partial\left[{ }^{4} \mathrm{He}\right]}{\partial t}=D(t)\left(\frac{\partial^{2}\left[{ }^{4} \mathrm{He}\right]}{\partial r^{2}}+\frac{2}{r} \frac{\partial\left[{ }^{4} \mathrm{He}\right]}{\partial r}\right)+P,
$$

where $\left[{ }^{4} \mathrm{He}\right]$ is the ${ }^{4} \mathrm{He}$ concentration and $P$ is the $\mathrm{He}$ production rate due to the decay series of ${ }^{232} \mathrm{Th},{ }^{235} \mathrm{U}$, and ${ }^{238} \mathrm{U}$ [Braun et al., 2006]. $D(t)$ is the temperaturedependent He diffusion coefficient in the crystal considered such as

$$
D(t)=D_{0} e^{-E_{a} / R T(t)},
$$

with $E_{a}$ the activation energy and $R$ the universal gas constant. In the following, and for zircons, we used values of $E_{a}=169 \mathrm{~kJ} \mathrm{~mol}^{-1}$ and $D_{0}=0.46 \mathrm{~cm}^{2} \mathrm{~s}^{-1}$ [Reiners et al., 2004]. The numerical solution to equation (2) was validated by comparison with the analytical formulation of Wolf et al. [1998].

[26] Grain size has an important effect on diffusion processes, as larger grains lead to higher equilibration time relatively to smaller grains. The zircons considered in this study have roughly a parallelepipedic shape. Following Dunai [2005], we use a grain radius $R$ that preserve the surface/volume ratio $\beta_{m}$ observed in the zircons (Figure 6, here $R=3 / \beta_{m} \simeq 67 \mu \mathrm{m}$ ).

\subsubsection{Comparison of Model Results With Data}

[27] On the basis of the structure of our age-elevation profiles and following previous studies (section 2.2) [Arne et al., 1997; Kirby et al., 2002; Clark et al., 2005b] we consider a two-step evolution and we use three parameters to describe the exhumation history for the studied area: (1) the exhumation rate for an old low exhumation period, (2) the exhumation rate for a recent rapid exhumation period, and (3) the transition age between those two periods. For each parameter, we assign a range of variation, and a systematic exploration of the parameter space is performed. This allows us to simulate a thermal evolution and the associated synthetic age-elevation transect for each combination of those three parameters. This synthetic transect is compared with the data from Wenchuan and Xuelongbao profiles, which present the most complete exhumation history of our data set (Figure 4). We exclude sample LM229 from the comparison, as it is off the general trend

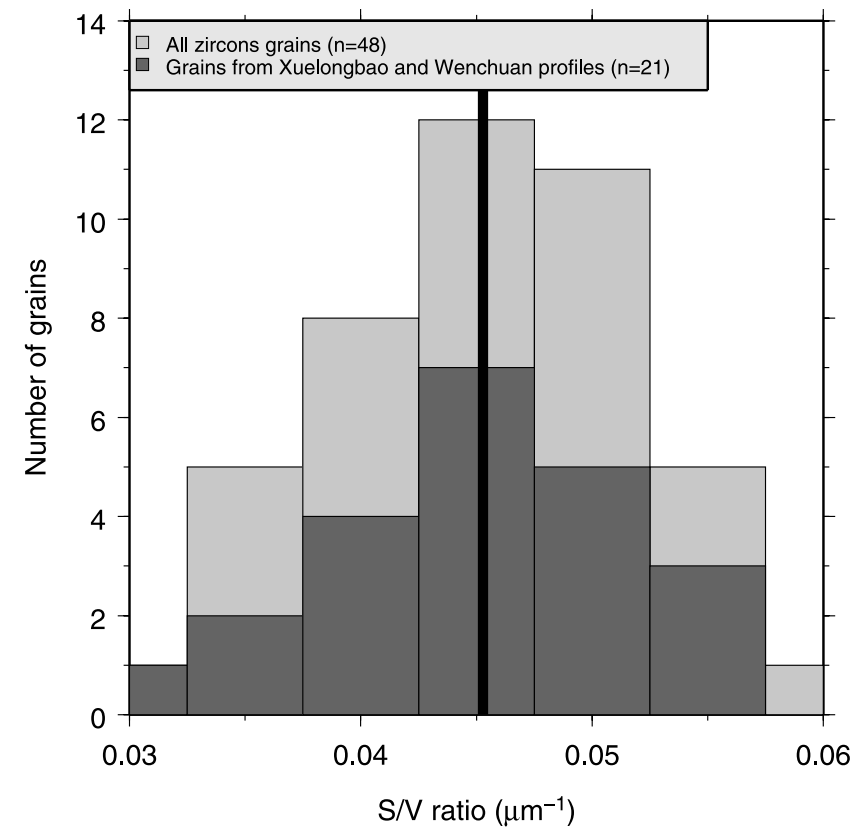

Figure 6. Histograms for values of the surface to volume ratio, for the analyzed zircon population. The vertical black line gives the mean value of the ratio for the zircons grains of Xuelongbao and Wenchuan transects, which are used for the modeling. 

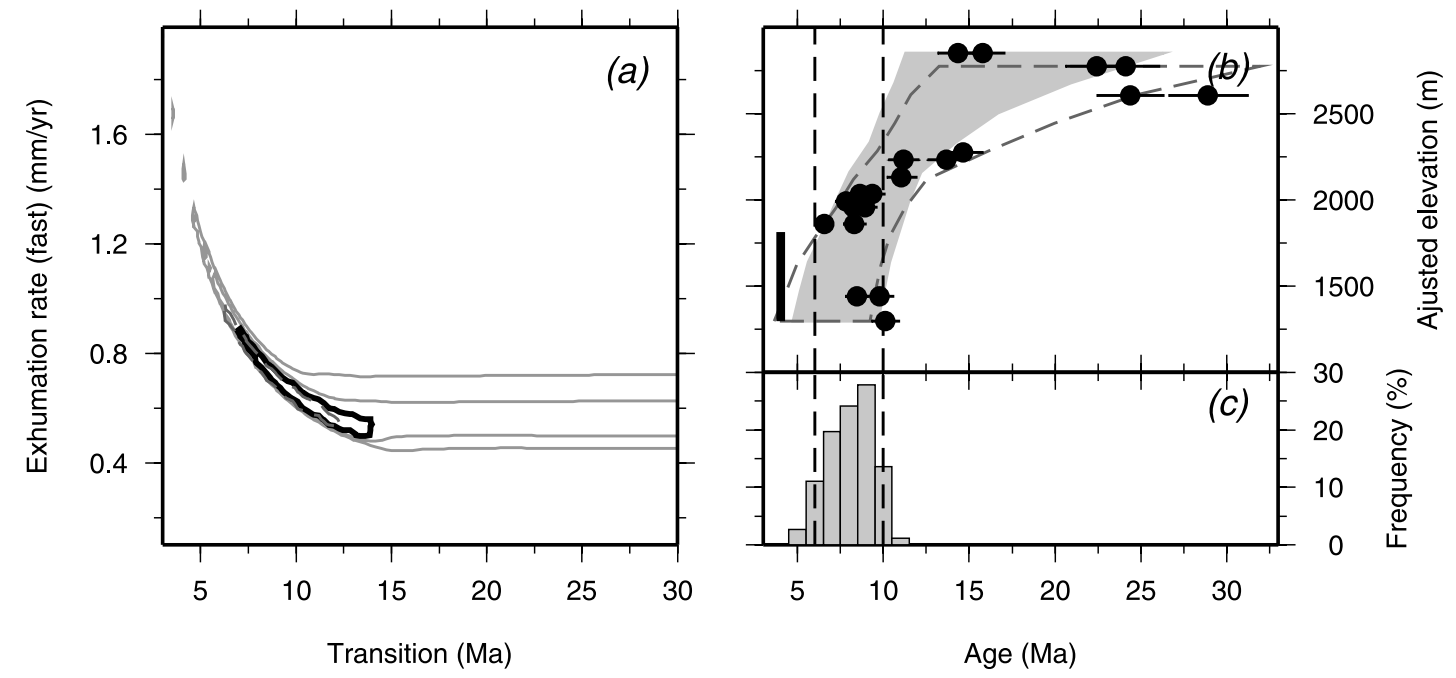

Figure 7. Results of the forward modeling with data from the Xuelongbao and Wenchuan profiles (Figure 4). The exhumation rate during the ancient slow exhumation period is fixed to $0.01 \mathrm{~mm} \mathrm{a}{ }^{-1}$. (a) Black contour indicates the position of the $1 \%$ best fitting solutions over the whole set of simulations. Light grey contours indicate the 5\% and 10\% contours. Dark grey dashed contour indicates the $1 \%$ best fitting solutions obtained when we exclude the uppermost sample of Wenchuan transect (LM225). (b) Envelope (grey surface) of the $1 \%$ best fitting synthetic transects. Dark grey dashed contour corresponds to the case when LM225 is excluded. Black circles indicates data from Wenchuan and Xuelongbao profiles that are used for the computation of the match criterion. Note that the elevation of the data points from Wenchuan profile have been adjusted by shifting $200 \mathrm{~m}$ downward with respect to what is presented on Figure 4 and Table 1. (c) Histogram of synthetic ages for the lowest part of the profiles, between 1300 and $1800 \mathrm{~m}$ (as indicated by vertical black bar in Figure 7b).

defined by the data from Wenchuan profile and lies geographically away from this profile. We introduce a vertical offset of $200 \mathrm{~m}$ downward, for the data from the Wenchuan profile, to make those points match the upper part of the Xuelongbao profile. This allows us to work on a continuous transect by removing the influence of a small-scale offset due either to a local undulation associated with a folding of the PRZ, to the geometry of the initial topography, or more likely to minor dip-slip faulting on the WFZ. We make the assumption that the WFZ is the only major tectonic disturbance across the two transects. We also neglect the eventual differences in radiation damage between the Xuelongbao Pluton and the Pengguan Massif [Shuster et al., 2006]. Indeed, even if the relationship between those two units is still debated we note that Zhou et al. [2006] propose that the Xuelongbao Pluton belongs to the same Proterozoic basement formation as the Pengguan Massif.

[28] Because with this approach we examined the space defined by variations of the three parameters, we need to evaluate the similarity between the simulated age-elevation transect and the data. For that purpose we define a match criterion associated with each synthetic transect. This criterion is based on the misfit function used by Braun and Robert [2005]:

$$
\text { misfit }=\frac{1}{N_{\text {data }}} \sqrt{\sum_{i=1}^{N_{\text {data }}}\left(\frac{X_{i}^{\text {data }}-X_{i}^{\text {model }}}{\sigma_{i}}\right)^{2}},
$$

where $N_{\text {data }}$ is the total number of individual data points, $X^{\text {data }}$ and $X^{\text {model }}$ are the data and model age vectors, respectively, and $\sigma_{i}$ is the uncertainty vector associated with the data. A misfit value is calculated for all the synthetic transects and is used to extract the best centile (1\% best fitting scenarios) out of whole group of simulations.

\subsection{Results}

\subsubsection{Reference Model}

[29] Results obtained with the reference thermal parameters (Table 3) are detailed in Figure 7 and highlight a clear trade-off between the age of onset for active denudation and the exhumation rate (Figure 7a). This is imposed by the necessity to exhume a given quantity of crust corresponding to the depth of the PRZ. We do not present results associated with the exploration of different values for the exhumation rate during slow exhumation periods. Indeed, it appears that the outputs of our modeling and the pattern of Figure 7 are quite insensitive to modification of this parameter in the $0-0.1 \mathrm{~mm} \mathrm{a}^{-1}$ range. This suggests that the uncertainty associated with the trend proposed for the Wenchuan transect (Figure 4) does not significantly impact the outcome of our modelings. Furthermore, it can be seen that excluding sample LM225 from our simulation allows for a better fit of the oldest ages (Figure 7b), however this does not significantly change the parameter range associated with the best fitting solutions (Figure 7a). 


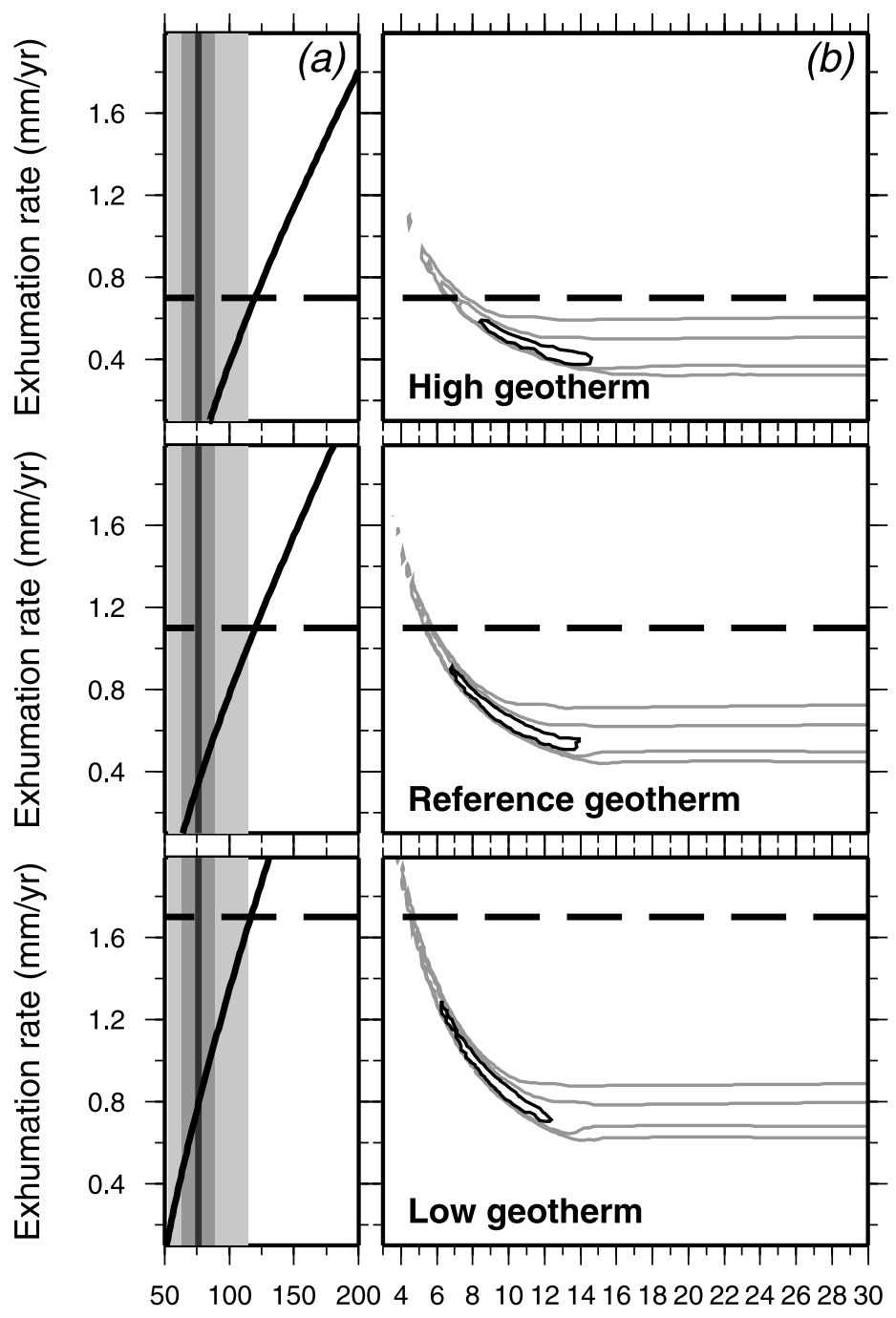

Heat flow $\left(\mathrm{mW} / \mathrm{m}^{2}\right)$

transition (Ma)
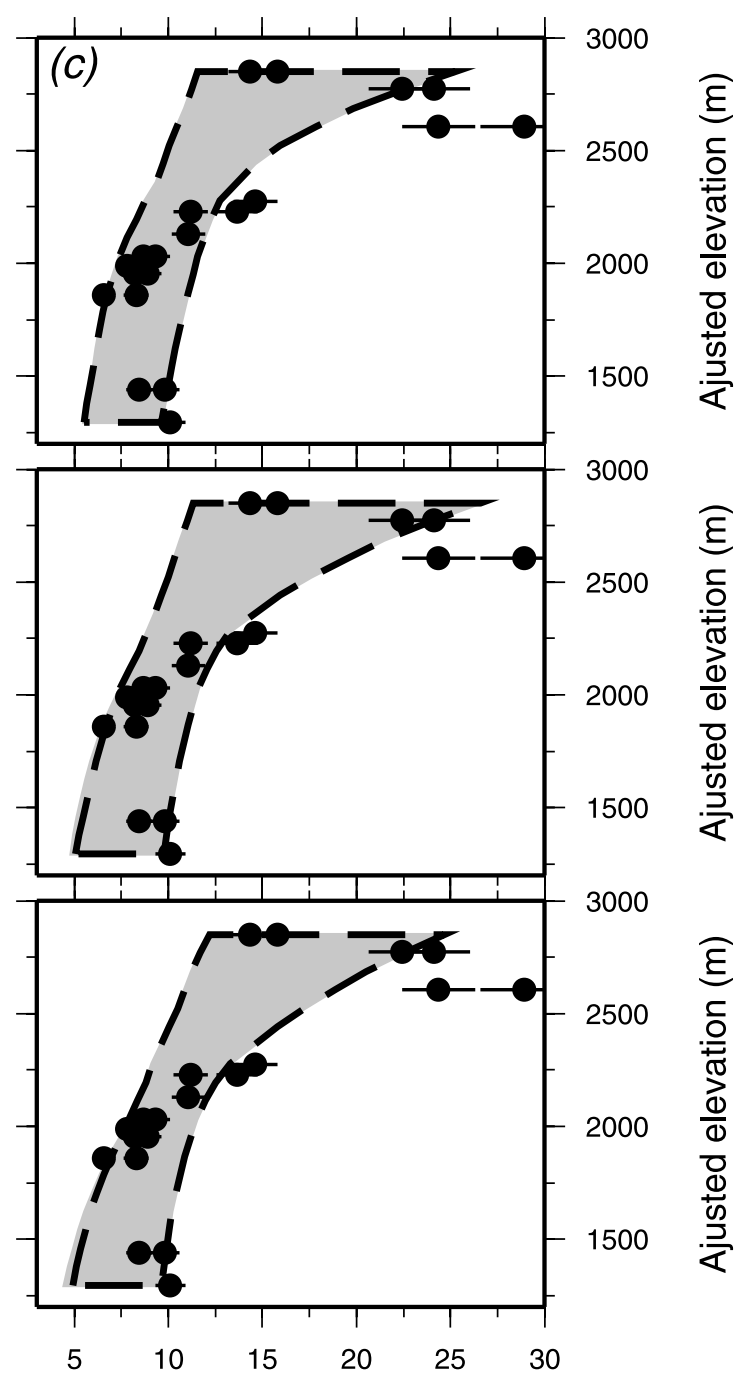

$\widehat{\xi}$
$\frac{0}{0}$
$\frac{0}{0}$
$\frac{0}{0}$
$\frac{0}{0}$
$\frac{9}{00}$
$\frac{0}{4}$

Figure 8. Result of the forward modeling of the He ages for the various thermal conditions (Table 3). (a) Surface heat flow associated with the imposed denudation rate (solid black lines) and data set from $\mathrm{Hu}$ et al. [2000] (from dark to light greys are mean, $\pm 1 \sigma$, and extremal values). Horizontal dashed lines indicate the limit above which exhumation rates imply heat flows that exceed the maximal reported regional value. Such exhumation values are considered as unrealistic. (b) Black contour indicates the position of the $1 \%$ best fitting solutions out of the whole set of simulations, grey contours indicate 5 and $10 \%$ (same as Figure 7). (c) Envelope (grey surface) of the 1\% best fitting synthetic transects with same data set as Figure 7. The thick dashed black line encompasses only transects that are associated with realistic heat flow values.

[30] The most likely values are $0.5-0.9 \mathrm{~mm} \mathrm{a}^{-1}$ and $6-$ $13 \mathrm{Ma}$ for the exhumation rate and the transition age, respectively. A histogram for the distribution of the simulated ages in the lowest part of the profiles (1300-1800 m) shows that most of those ages are between 8 and $11 \mathrm{Ma}$, which is consistent with the data from Xuelongbao transect (Figure 7c).

\subsubsection{Influence of Thermal Conditions}

[31] In addition to the reference model, we estimate the influence of crustal thermal conditions on our interpretation of the data, by testing the effects of the high and low hypotheses (Table 3). Figure 8 presents forward modeling of the He ages for those three sets of thermal parameters. As previously mentioned, our results are nonsensitive to the rate of exhumation over the oldest period, so in the following, we set this parameter to $0.01 \mathrm{~mm} \mathrm{a}^{-1}$, which is consistent with current estimates of the erosion acting inside the plateau [Lal et al., 2004]. The exploration is thus conducted with only two parameters, the age of onset of active denudation and the corresponding exhumation rate. 
[32] To better constrain the thermal regime, the calculated surface heat flow is compared to available data $[\mathrm{Hu}$ et al., 2000]. Higher exhumation rates lead to higher heat flows. We consider as unrealistic all the simulations that give out final heat flows exceeding the current maximum regional reported value [Hu et al., 2000]. In the case of the high geotherm hypothesis, this heat flow limit is a very constraining criterion that excludes all the simulations with exhumation values greater than $\sim 0.7 \mathrm{~mm} \mathrm{a}^{-1}$. However, it appears that all the best fitting solutions for the three

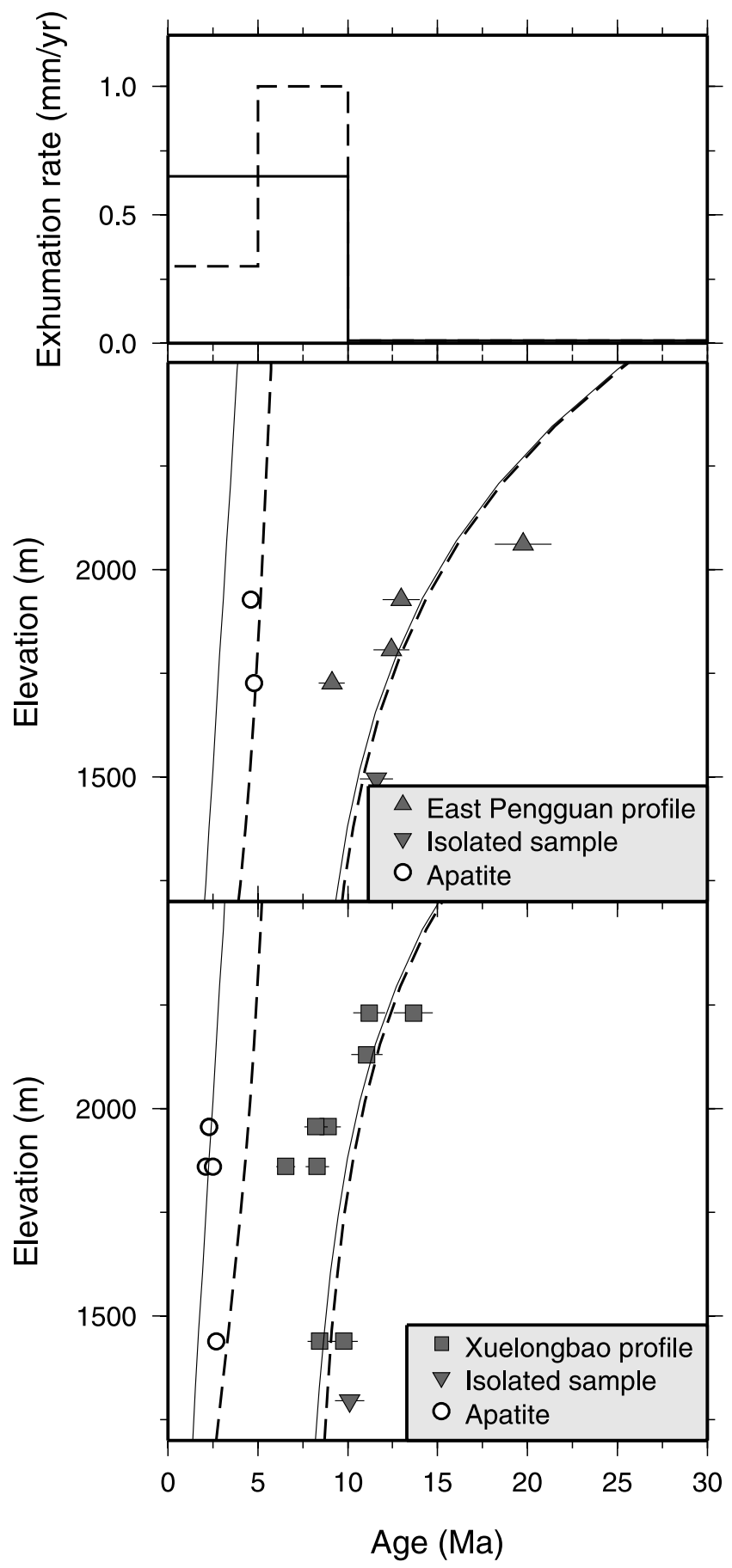

geotherms are associated with exhumation rates that are compatible with this heat flow criterion (Figure 8b).

[33] The ranges of variation of the transition age are 511, 6-12, and 8-14 Ma for the low, reference and high geotherms, respectively. It corresponds to ranges of 0.8 $1.5,0.5-0.9$, and $0.4-0.6 \mathrm{~mm} \mathrm{a}^{-1}$ for the exhumation rate. Considering the whole spectrum of thermal conditions, it allows us to propose that the most likely values are $0.5-0.8$ $\mathrm{mm} \mathrm{a}{ }^{-1}$ for the exhumation rate and $8-11 \mathrm{Ma}$ for the transition age.

[34] One can note that the product of the exhumation rate with the transition age corresponds to the thickness of the eroded crust. The best fitting scenarios, on Figure 8, are those where this thickness is close to the closure temperature depth. The PRZ is shallower with hot crustal conditions, which implies that the thickness of the crust to be eroded to obtain a good fitting scenario is smaller in this case. This explains why the higher geotherms leads to lower exhumation rates.

\subsubsection{Comparison of Zircon and Apatite Ages}

[35] Comparison of the ages obtained on zircons and apatites suggests the existence of differences in the evolution of exhumation across the Longmen Shan. For that reason, we have tested the implications of two distinct exhumation histories (Figure 9). The first scenario corresponds to a steady exhumation rate scenario, i.e., to the best estimate of the exhumation rate and transition date obtained above, which are $0.65 \mathrm{~mm} \mathrm{a}^{-1}$ and $10 \mathrm{Ma}$, respectively. The second scenario considers similar total exhumation since $10 \mathrm{Ma}$ but including an unsteady exhumation rate: high exhumation rate at $1 \mathrm{~mm} \mathrm{a}^{-1}$ between 10 and $5 \mathrm{Ma}$ followed by a threefold decrease in exhumation rate $\left(0.3 \mathrm{~mm} \mathrm{a}^{-1}\right)$ in recent times (from 5 to $0 \mathrm{Ma}$ ). Our modeling results indicate that the apatite ages from the Xuelongbao transect are consistent with the constant exhumation scenario. In contrast, an unsteady exhumation scenario, with a recent shift to subdued exhumation, seems required to explain the older apatite ages observed in samples of the East Pengguan transect. Even if more apatite ages are needed to further document those contrasting evolutions, the results described above suggests the most frontal part of the range may have experienced a recent

Figure 9. Forward modeling of the $\mathrm{He}$ ages for both apatite and zircon compared to data from the Xuelongbao and East Pengguan transects (Figure 4). Two different exhumation histories are considered, one with constant exhumation since $10 \mathrm{Ma}$ (solid curves) and one with an important decrease of exhumation at $3 \mathrm{Ma}$ (dashed curves). The parameters are the same as those used with our reference model (Figure 7). Helium diffusion parameters for apatite are from Farley [2000]. Despite 3-D thermal modeling being better suited to model low closure temperature apatite ages, it has to be noted that both sets of data are coming from the bottom of valleys with similar width and ridge/valley relief. In both valleys, the isotherms are suspected to have been deflected in a similar way and do not affect the relative differences observed in apatite or zircon ages. 


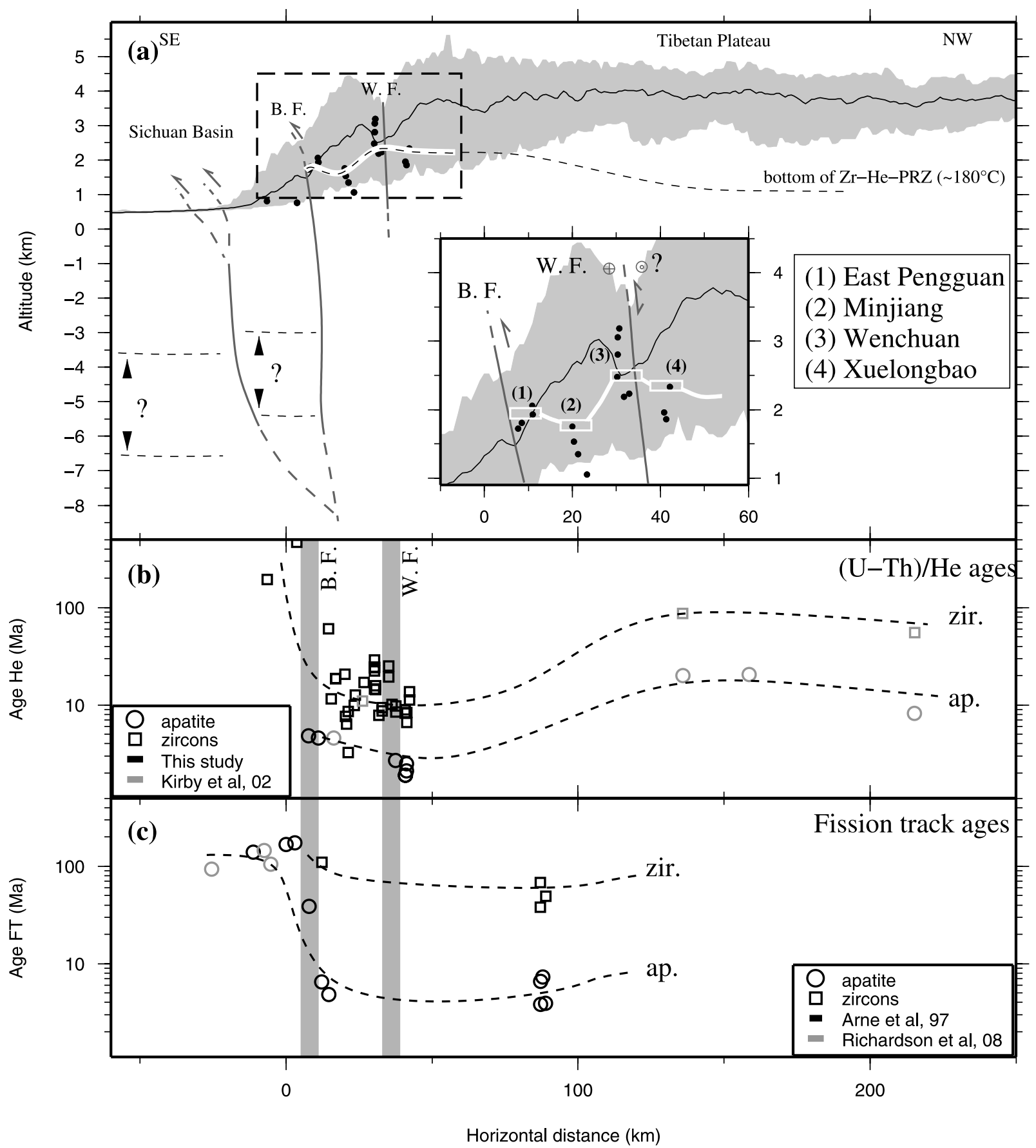

Figure 10. (a) Topographic cross section (N315) with projected data points collected in this study, with an inset presenting a zoom on the Longmen Shan region. White boxes, in the inset, indicate the position of the base of the exhumed fossil zircon (U-Th)/He partial retention zone (PRZ) inferred from the lowest elevation of the shallow slope trends of our profiles. Solid white line indicates the interpolated position of the base of this PRZ. Dashed black line indicates propositions for the prolongation of this PRZ west and east of the margin. ( $b$ and c) Projection of low-temperature thermochronology data sets. Fission track data from Arne et al. [1997], (U-Th)/He data from Kirby et al. [2002] and this study. Swath width is $50 \mathrm{~km}$. The dashed lines indicate propositions of interpolation and extrapolation of the distribution of the ages across the margin. 
decrease ( 2 to 3 folds) in exhumation, while conditions remained relatively steady farther west.

\section{Discussion}

\subsection{Spatial Pattern of Denudation Across the Margin and Activity of the Major Structures}

[36] The age-elevation transects presented here allow us to draw an elevation profile of the fossil zircon (U-Th)/He PRZ across the margin (Figure 10). Compilation of isolated thermochronological data from this study and from the literature permits us, in addition, to roughly extend this profile laterally farther east and west.

[37] The regional distribution of $(\mathrm{U}-\mathrm{Th}) / \mathrm{He}$ zircon and apatite ages (Figure 10b) shows that the youngest ages are located inside the Pengguan basement core, west of the BF. As pointed out by Kirby et al. [2002], samples located farther west on the plateau present significantly older ages. However, the cluster of young apatite FT ages [Arne et al., 1997] on the plateau suggests that the area where significant exhumation has been active since mid-Miocene is not strictly limited to the Pengguan-Xuelongbao area, but extends significantly farther west.

[38] In the absence of evidence for the existence of largescale extensional structures in the central Longmen Shan we consider that exhumation is mostly accommodated through erosion. Thermochronologic ages and, more particularly, the fossil PRZ (Figure 10a), permit documentation of vertical offsets across the main faults of the range. This requires the assumption that the primary driver of short-wavelength variations in exhumation is tectonics and differential rock uplift across faults that imply differences in the amount of denudation, rather than spatial variations in climate. We note that the current precipitation pattern over the Longmen Shan is relatively homogeneous and presents no significant variation at a $\sim 100 \mathrm{~km}$ length scale [New et al., 2002].

[39] For the sedimentary folded series of the Sichuan Basin, in the foothills east of the BF, several studies have documented (1) partially reset to unreset apatite FT ages [Arne et al., 1997; Richardson et al., 2008] $\left(60^{\circ} \mathrm{C}<\right.$ $T_{\text {annealing }}<110^{\circ} \mathrm{C}$ [Ketcham et al., 1999], $2 \mathrm{~km}<z_{c}<$ $4.5 \mathrm{~km}$, with a $20^{\circ} \mathrm{C} \mathrm{km}^{-1}$ geotherm proposed by Richardson et al. [2008] and $T_{\text {surface }}=20^{\circ} \mathrm{C}$ ) and (2) unreset zircon (U-Th) $/ \mathrm{He}$ ages (this study, $T_{c} \sim 180^{\circ} \mathrm{C}$ [Reiners, 2005], $\left.z_{c} \sim 8 \mathrm{~km}\right)$. The mix of reset and partially reset FT ages allow us to estimate that the area underwent $2-4.5 \mathrm{~km}$ of exhumation, corresponding to the exhumation of the partial annealing zone for apatite. It implies that the fossil zircon (U-Th)/He PRZ was exhumed from its initial depth of $\sim 8 \mathrm{~km}$ to $3.5-6 \mathrm{~km}$ below the surface.

[40] In the basin itself, Richardson et al. [2008] propose that the exhumation was $1-4 \mathrm{~km}$, which implies that the fossil PRZ is now at $4-7 \mathrm{~km}$ below the surface. This inference of the respective positions of the fossil PRZ below the basin and the foothills suggests that more exhumation occurred in the foothills and that some amount of shortening may have been accommodated across the most frontal thrust, which is located east of the BF (Figure 10c). However, a precise quantification of this differential uplift would require further focused sampling across those frontal structures. On a shorter timescale, such uplift of the foothills, with respect to the Sichuan Basin, is also recorded by a set of fluvial terraces abandoned by the frontal rivers, with an average rate of $0.5 \mathrm{~mm} \mathrm{a}^{-1}$ over the late Pleistocene [Godard, 2006].

[41] Conversely, we observe that the fossil zircon PRZ is exposed inside the Pengguan Massif. This indicates a vertical offset of 5-7.5 km of this fossil PRZ across the BF. The present difference in mean elevation between the sampling zone of the East Pengguan profile and the samples taken in the frontal units is less than $1 \mathrm{~km}$. The fact that the erosion rates prior to $10 \mathrm{Ma}$ are $<0.02 \mathrm{~mm} \mathrm{a}^{-1}$ suggests that the regional topographic gradient was more subdued than today and that the difference in elevation of the initial PRZ across the $\mathrm{BF}$ was $<1 \mathrm{~km}$. In consequence, since the midMiocene, the $\mathrm{BF}$ has accommodated 4 to $6.5 \mathrm{~km}$ of differential exhumation by thrusting activity and associated denudation, between the Pengguan Massif and the frontal foothills. This represents at least $60 \%$ of the total exhumation of the Central Longmen Shan and shows that the BF is probably the most active structure of the area. The May 2008 Sichuan earthquake was associated with significant strike-slip motion along the BF [Lin et al., 2009; C. Ji and G. Hayes, Preliminary result of the May 12, 2008 MW 7.9 eastern Sichuan earthquake, 2008, available at http://earthquake.usgs.gov, hereinafter referred to as Ji and Hayes, 2008]. When extrapolated on the long term, such kinematics can influence the thermal structure due to along strike variations in topography or lithology. In the above calculation we do not consider this possible effect and make the assumption that the structure is cylindrical, which is appropriate for the part of the $\mathrm{BF}$ we are interested in.

[42] Farther west, the comparison of Xuelongbao and Wenchuan transects indicates minimal $(\sim 200 \mathrm{~m})$ normal offset of the fossil PRZ across the WFZ. As both sides of the fault experienced enough denudation to exhume the fossil PRZ $(6-7 \mathrm{~km})$, this does not fit with the idea of an important dip slip activity of the WFZ during that time. It can be noted that, on the basis of our data set, we cannot assess the amplitude of an eventual strike slip motion [Burchfiel et al., 1995]. However, the topographic variations along the WFZ are relatively small and we make the assumption that the thermal structure and history are similar on both side of the fault. From this point of view, our study does not support the assumption that this fault zone would have accommodated significant differential exhumation between the Longmen Shan and the Tibetan Plateau since $10 \mathrm{Ma}$. This absence of long term dip-slip activity on the WFZ, or more precisely the strong difference of exhumation accounted by the WFZ and the BF, contradicts recently published conceptual models which propose the existence 
of an uplifting pop-up structure between these two faults [Burchfiel, 2004; Meng et al., 2006].

\subsection{Geodynamical Evolution}

\subsubsection{Creation of Topography and Tectonic Imprint}

[43] Several mechanisms can be invoked to explain the late Cenozoic evolution of the Longmen Shan region [Clark and Royden, 2000; Wilson et al., 2006], such as (1) the climatically driven onset of active erosion of a preexisting topography, (2) the eastward propagation of a midcrustal channel flow below the Tibetan Plateau, which would diverge around the rigid Sichuan craton [Clark et al., 2005a], and (3) the onset of an important tectonic event initiating thrusting activity and exhumation along the margin. We analyze below the arguments and implications of each hypothesis.

\subsubsection{Erosional Hypothesis}

[44] It has been proposed that earlier orogenesis might have contributed to topographic construction and that the region was probably already significantly elevated prior to the $10 \mathrm{Ma}$ event [Mattauer et al., 1992; Harrowfield and Wilson, 2005]. A drastic environmental change, as the one triggered at $8-9 \mathrm{Ma}$ by the onset of the southeast Asian Monsoon [An et al., 2001], would introduce more precipitation in the area and strongly enhance exhumation intensity. This possibility has been invoked by Clark et al. [2005b], to explain the onset of active fluvial incision in southeastern Tibet at that time. Such phenomena might have contributed to an increase in exhumation in the Central Longmen Shan as well. However, it is dubious that a transition to wetter climatic conditions was sufficient to explain an increase by a factor $>30$ (from 0.02 to $0.65 \mathrm{~mm}$ $\mathrm{a}^{-1}$ ) of the exhumation rates. As underlined by Kirby et al. [2002], the coexistence of a low exhumation rate and high topographic gradient prior to $10 \mathrm{Ma}$ is unlikely, as it would require unrealistically dry climatic conditions for this area. In any case, it is difficult to impute the building of the observed topographic front, and more importantly the vertical offset across the BF, solely to the contribution of an isostatic response to erosional unloading.

[45] Alternatively, the onset of exhumation could have been triggered by a sudden base level fall. Richardson et al. [2008] have recently proposed that the Sichuan Basin have experienced a massive exhumation event starting at $40 \mathrm{Ma}$, associated with 1 to $4 \mathrm{~km}$ of sediment removal. The base level fall associated with such an event should have initiated the propagation of a regressive erosion wave across the margin. However, this event is much older than the initiation of the major Miocene exhumation phase reported by this study and other authors. But more importantly, we note that (1) the westward decrease of exhumation, that would be associated with regressive erosion, is incompatible with the exhumation gradient observed between the frontal Mesozoic folded units and the Pengguan massif and (2) the 6-7 km of exhumation in the Longmen Shan since $10 \mathrm{Ma}$ is too large to be attributed to a base level fall of $1-4 \mathrm{~km}$. To explain the spatial variations in ages, in particular across the $\mathrm{BF}$, it seems inescapable that tectonic forcing has contributed to a significant amount to the exhumation and topographic building in this region during late Cenozoic.

\subsubsection{Channel Flow Models}

[46] In order to overcome the apparent contradiction between the high topographic gradients and the lack of active shortening across the Longmen Shan, it has been proposed that the evolution of the region is controlled by the propagation of low-viscosity material in the middle crust, from the plateau, toward the foreland [Royden et al., 1997; Kirby et al., 2000]. This would promote the eastward propagation of a gentle and progressive topographic step at the tip of the channel flow. The flow would be laterally deviated by the cold and rigid block of the Yangtze craton under the Sichuan basin, which would force upward movement of material and surface uplift in the Longmen Shan [Clark and Royden, 2000; Meng et al., 2006]. Such model predicts lower exhumation rates westward and is consistent with the increase of the ages and decrease in exhumation toward the plateau, as well as the low exhumation of the frontal folded Mesozoic units. As pointed out by Clark et al. [2005a], the existence of structures that accommodate vertical doming at the tip of the channel flow and horizontal extension due to upward flexure of the upper crust may be a critical distinguishing expression of channel flow processes at regional scale. From our results, it appears that the WFZ, which is one of the most prominent tectonic features of the Central Longmen Shan, is not a likely candidate to accommodate such recent extension, nor to permit the vertical extrusion of a pop-up bordered by the WFZ and BF [Meng et al., 2006].

[47] Whereas simplified models of flexure imposed by a pressure gradient predict broad wavelength and continuous deformation at the surface [Clark et al., 2005a], we could imagine that the upper crust deforms brittley at some stage under flexuration due to pressure excess in the lower crust, and that the BF connects at depth to the tip of the midcrustal channel flow [Burchfiel et al., 2008]. However, kinematically the BF activity implies some regional convergence. In the framework of the channel flow model, this would imply some degree of coupling between the midcrustal lowviscosity zone and the upper crust, as in a Couette flow.

\subsubsection{Mid-Miocene Increase of Convergence Across} the East Tibetan Margin

[48] According to our data, at least $60 \%$ of the PRZ exhumation since mid-Miocene has been accommodated by active thrusting on the BF. We therefore suggest that active thrusting across this structure is the major factor responsible for late Cenozoic topographic building in the Longmen Shan and the slow exhumation of the Pengguan Massif. It is also consistent with the mechanism of the May 2008 Sichuan earthquake (U.S. Geological Survey, 2008, National Earthquake Information Center, http://earthquake.usgs.gov). Assuming a dip angle of $30^{\circ}$ to $50^{\circ}$ for the $\mathrm{BF}$ at depth, as given by focal solutions of this seismic event. The 
vertical offset leads to an associated finite slip of 4 to $10 \mathrm{~km}$ and, since $10 \mathrm{Ma}$, a mean slip rate of $0.4-1 \mathrm{~mm} \mathrm{a}^{-1}$ across the fault. Such a low slip rate is compatible with the low current GPS estimates for the shortening rate across the Longmen Shan $\left(<3 \mathrm{~mm} \mathrm{a}^{-1}\right)$. However, the gap in timescales between geodetics, seismologic and low-temperature thermochronology data should be handled with caution. In particular, we can hardly document the constancy of the tectonic activity since its onset at $\sim 10 \mathrm{Ma}$.

[49] The reduced set of (U,Th)/He apatite vs zircon ages suggests that exhumation has not been constant since $10 \mathrm{Ma}$ throughout the Longmen Shan. The apatite ages of the frontal watersheds (East Pengguan profile, and sample 933 (4.6 Ma) of Kirby et al. [2002]) indicate that exhumation rate could have decreased by a factor of two or more during the Plio-Pleistocene (Figure 9). Meanwhile it has remained constant and elevated in the more internal parts (Xuelongbao profile). Sudden tectonic activity on the $\mathrm{BF}$ and topographic building at $\sim 10$ Ma followed by more subdued activity would produce the progressive propagation of a regressive denudation wave, from the footwall of the $\mathrm{BF}$ toward the plateau interior and low-order segments of the river network. Once the regressive wave has affected a region, it would be followed by a progressive decrease of the erosion rate toward the Plio-Pleistocene values. Such decay being delayed in the upstream direction, it would explain why the frontal watersheds have already recorded the erosion rate decrease in contrast with the more upstream parts. The frontal part of the margin would have experienced an early and complete exhumation of the fossil PRZ, with young ages in the valleys bottoms. Meanwhile, farther west, i.e., at distance $>50-100 \mathrm{~km}$ from the $\mathrm{BF}$, the denudation would not have propagated enough to produce as much exhumation, and old ages, from above the PRZ, are still observed. Our apatite data set is for the moment insufficient to draw definitive conclusions on a potential tectonic pulse followed by less intense tectonic activity, but this particular issue probably deserves future focused thermochronological studies.

\subsubsection{Regional Geodynamical Evolution}

[50] Our study supports a two-step history for the Central Longmen Shan with subdued exhumation before the middle-late Miocene, and a sudden increase of relief and exhumation around $10 \mathrm{Ma}$, at a mean rate of $0.65 \mathrm{~mm}$ $\mathrm{a}^{-1}$. This may be followed by a progressive decrease in tectonic activity. Our work is consistent with a regional increase in exhumation rate across eastern Tibet circa 9-13 Ma. Notably finite exhumation has been two times higher in the Longmen Shan than elsewhere [Clark et al., 2005b]. Farther north, denudation rates are lower and the exhumation pulse, around 9-4 Ma in the southern Qinling [Enkelmann et al., 2006], slightly postdates the initiation of exhumation in the Longmen Shan.

[51] It could be tempting to correlate such regional exhumation onset with a regional change in climatic [Clark et al., $2005 \mathrm{~b}$ ] or tectonic conditions. We already discussed in section 6.2.1.1 the difficulties to reconcile the climatic hypothesis with the amplitude and the spatial variations of our thermochronologic data in the Longmen Shan. Conversely, the activity on the BF, as well as on the strike slip faults of the southern Qinling [Enkelmann et al., 2006], could indicate a major episode of building of the eastern and northeastern Tibetan Plateau since the middle to late Miocene. According to previous work, such a synchronous building episode could result from the eastward propagation of a midcrustal channel flow all over the eastern Tibetan Plateau [Clark et al., 2005a], or from the Oligo-Miocene stepwise development of the central and northern Tibetan Plateau in a general context of eastward extrusion [Tapponnier et al., 2001].

[52] However, neither of these end-member models can completely explain our observations in the Central Longmen Shan. First, we previously saw that our data suggests that some shortening in the upper crust is needed in addition to deep crustal processes. Second, the tectonic model of Tapponnier et al. [2001], as developed in more detail by Replumaz and Tapponnier [2003], suggests that Songpan terranes would have overthrusted the Sichuan basin during the 30-15 Ma interval, i.e., significantly earlier than the onset of the exhumation recorded by the thermochronological data. Finally, even if present structural and thermochronological data are insufficient to propose an alternative regional geodynamic model, our data provide new estimations on exhumation amplitude, rates and timing that must be honored by any future evolution model for eastern Tibet.

\section{Conclusion}

[53] The high-density data set provided by our study allow us to precise some of the characteristics of the exhumation history of the Central Longmen Shan. The age range of the young samples in the lowermost part of our transects and our numerical modeling point to an initiation of active exhumation between 8 and $11 \mathrm{Ma}$, with rates $\sim 0.65 \mathrm{~mm} \mathrm{a}^{-1}$. Our results also provides a consistent basis for discussing the activity of the two main structures of this margin. No important dip slip motion occurred across the Wenchuan Fault Zone, whereas the Beichuan Fault accommodated significant shortening and exhumation since $10 \mathrm{Ma}$. The persistent activity and slow stress accumulation on this structure was illustrated by the 2008 Sichuan earthquake. The average dip slip component of the rupture reaches $\sim 5 \mathrm{~m}$ along the Pengguan massif ( $\mathrm{Ji}$ and Hayes, 2008). Given a slip rate $<1 \mathrm{~mm} \mathrm{a}^{-1}$ on the Beichuan Fault the recurrence time of an earthquake of this magnitude would be larger than 5000 years.

[54] Our data and associated interpretations are compatible with channel flow mechanisms that are often proposed to explain the peculiar feature of this region. Nevertheless, the constraints that we provide concerning the amount of exhumation accommodated across the major structures allow us to critically discuss the conceptual models appealing to such processes [Meng et al., 2006] and to propose additional or alternative factors for the development of the Longmen Shan since the Miocene. In particular, thrusting tectonics on the Beichuan Fault had a major role for the development of this plateau margin. Topographic inflation 
driven by pressure gradients within a midcrustal channel flow may have contributed, but it was probably not the sole mechanism involved.

[55] Acknowledgments. This work was funded by an INSU-Relief grant and the ANR ContinentDyn. Chengdu University of Technology staff provided assistance in the organization of the field work. The manuscript benefited from thorough comments and syntax corrections by Juliet Crider and Robert Finkel. Peter Reiners, Chris Wilson, and an anonymous reviewer comments helped to clarify an earlier version of this paper. Reviews and comments by Associate Editor Todd Ehlers, Mike Oskin, and an anonymous reviewer led to improvements of the article.

\section{References}

An, Z., J. E. Kutzbach, W. L. Prell, and S. C. Porter (2001), Evolution of Asian monsoons and phased uplift of the Himalayan Tibetan Plateau since late Miocene times, Nature, 411, 62-66, doi:10.1038/ 35075035 .

Arne, D., B. Worley, C. Wilson, S. F. Chen, D. Foster, Z. L. Luo, S. G. Liu, and P. Dirks (1997), Differential exhumation in response to episodic thrusting along the eastern margin of the Tibetan Plateau, Tectonophysics, 280, 239-256, doi:10.1016/ S0040-1951(97)00040-1.

Braun, J., and X. Robert (2005), Constraints on the rate of post-orogenic erosional decay from low-temperature thermochronological data: Application to the Dabie Shan, China, Earth Surf. Processes Landforms, 30, 1203-1225, doi:10.1002/esp.1271.

Braun, J., P. van der Beek, and G. Batt (2006), Quantitative Thermochronology: Numerical Methods for the Interpretation of Thermochronological Data, Cambridge Univ. Press, Cambridge, U. K.

Burchfiel, B. C. (2004), New technology: New geological challenges, GSA Today, 14, 4-10, doi:10.1130/1052-5173(2004)014<4:PANNGC $>$ 2.0.CO;2.

Burchfiel, B. C., Z. Chen, Y. Liu, and L. H. Royden (1995), Tectonics of the Longmen Shan and adjacent regions, central China, Int. Geol. Rev., 37, 661-735, doi:10.1080/00206819509465424.

Burchfiel, B. C., L. H. Royden, R. D. van der Hilst, B. H. Hager, Z. Chen, R. W. King, C. Li, J. Lü, H. Yao, and E. Kirby (2008), A geological and geophysical context for the Wenchuan earthquake of 12 May 2008, Sichuan, People's Republic of China, GSA Today, 18, 4-11, doi:10.1130/GSATG18A.1.

Chen, S. F., and C. J. L. Wilson (1996), Emplacement of the Longmen Shan Thrust-Nappe belt along the eastern margin of the Tibetan Plateau, J. Struct. Geol., 18, 413-430, doi:10.1016/0191-8141(95) 00096-V.

Chen, S. F. C. J. L. Wilson, and B. A. Worley (1995), Tectonic transition from the Songpan-Garze fold belt to the Sichuan Basin, southwestern China, $B a$ sin Res., 7, 235-253, doi:10.1111/j.1365-2117. 1995.tb00108.x.

Chen, Z., B. C. Burchfiel, Y. Liu, R. W. King, L. H Royden, W. Tang, E. Wang, J. Zhao, and X. Zhang (2000), Global Positioning System measurement from eastern Tibet and their implications for India/ Eurasia intercontinental deformation, J. Geophys Res., 105, 16,215-16,227, doi:10.1029/ 2000JB900092.

Clark, M. K., and L. H. Royden (2000), Topographic ooze: Building the eastern margin of Tibet by lower crustal flow, Geology, 28, 703-706, doi:10.1130/ 0091-7613(2000)28<703:TOBTEM $>2.0 . C O ; 2$

Clark, M. K., J. W. M. Bush, and L. H. Royden (2005a), Dynamic topography produced by lower crustal flow against rheological strength heterogeneities bordering the Tibetan Plateau, Geophys. J. Int., 162, 575-590, doi:10.1111/j.1365-246X.2005. 02580.x.

Clark, M. K., M. A. House, L. H. Royden, K. X. Whipple, B. C. Burchfiel, X. Zhang, and W. Tang (2005b), Late Cenozoic uplift of Southeastern Tibet, Geology, 33, $525-528$, doi: $10.1130 / \mathrm{G} 21265.1$
Densmore, A. L., M. A. Ellis, Y. Li, R. J. Zhou, G. S. Hancock, and N. Richardson (2007), Active tectonics of the Beichuan and Pengguan faults at the eastern margin of the Tibetan Plateau, Tectonics, 26 , TC4005, doi:10.1029/2006TC001987.

Dunai, T. J. (2005), Forward modeling and interpretation of $(\mathrm{U}-\mathrm{Th}) / \mathrm{He}$ ages, in Low-Temperature Thermochronology, Techniques, Interpretations, and Applications, Rev. Mineral. Geochem., vol. 58, edited by P. W. Reiners and T. A. Ehlers, pp. 259-274 Mineral. Soc. of Am., Chantilly, Va., doi:10.2138 rmg.2005.58.10

Ehlers, T. A., and K. A. Farley (2003), Apatite (U-Th) He thermochronometry: Methods and applications to problems in tectonics and surface processes, Earth Planet. Sci. Lett., 206, 1-14, doi:10.1016/ S0012-821X(02)01069-5.

England, P., and G. Houseman (1989), Extension during continental convergence, with application to the Tibetan Plateau, J. Geophys. Res., 94, 17,56117,579, doi:10.1029/JB094iB12p17561.

Enkelmann, E., L. Ratschbacher, R. Jonckheere, R. Nestler, M. Fleischer, R. Gloaguen, B. R. Hacker, Y. Q. Zhang, and Y. S. Ma (2006), Cenozoic exhumation and deformation of northeastern Tibet and the Qinling: Is Tibetan lower crustal flow diverging around the Sichuan Basin?, Geol. Soc. Am. Bull. 118, 651-671, doi:10.1130/B25805.1

Farley, K. A. (2000), Helium diffusion from apatite: General behavior as illustrated by Durango fluorapatite, J. Geophys. Res., 105, 2903-2914 doi:10.1029/1999JB900348.

Gan, W., P. Zhang, Z. K. Shen, Z. Niu, M. Wang, Y. Wan, D. Zhou, and J. Cheng (2007), Present-day crustal motion within the Tibetan Plateau inferred from GPS measurements, J. Geophys. Res., 112, B08416, doi:10.1029/2005JB004120.

Godard, V. (2006), Couplage érosion-tectonique en contexte de convergence intracontinentale. Étude comparée de la chaîne Himalayenne et des Longmen Shan (east-Tibet), Ph.D. thesis, Univ. Paris XI Ecole Normale Superieure, Paris.

Harrison, T. M., P. Copeland, W. S. F. Kidd, and A. Yin (1992), Raising Tibet, Science, 255, 1663-1670, doi:10.1126/science. 255.5052 .1663 .

Harrowfield, M. J., and C. J. L. Wilson (2005), Indosinian deformation of the Songpan Garze Fold Belt, northeast Tibetan Plateau, J. Struct. Geol., 27, $101-117$, doi:10.1016/j.jsg.2004.06.010.

Hodges, K. V. (2000), Tectonics of the Himalaya and southern Tibet from two perspectives, Geol. Soc. Am. Bull., 112, 324-350, doi:10.1130/00167606(2000)112<0324:TOTHAS $>2.3$.CO;2.

Hourigan, J. K., P. W. Reiners, and M. T. Brandon (2005), U-Th zonation-dependent alpha-ejection in (U-Th)/He chronometry, Geochim. Cosmochim. Acta, 69, 3349-3365, doi:10.1016/j.gca.2005. 01.024

Hu, S. B., L. J. He, and J. Y. Wang (2000), Heat flow in the continental area of China: A new data set, Earth Planet. Sci. Lett., 179, 407-419, doi:10.1016/ S0012-821X(00)00126-6.

Jiang, X., and Y. Jin (2005), Mapping the deep lithospheric structure beneath the eastern margin of the Tibetan Plateau from gravity anomalies, J. Geo- phys. Res., 110, B07407, doi:10.1029/ 2004JB003394

Ketcham, R. A., R. A. Donelick, and W. D. Carlson (1999), Variability of apatite fission-track annealing kinetics: III. Extrapolation to geological time scales, Am. Mineral., 84, $1235-1255$.

King, R. W., F. Shen, B. C. Burchfiel, L. H. Royden, E. Wang, Z. Chen, Y. Liu, X.-Y. Zhang, J.-X. Zhao, and Y. Li (1997), Geodetic measurements of crustal motion in southwest China, Geology, 25, 179-182, doi:10.1130/0091-7613(1997)025<0179:GMOCMI> 2.3. $\mathrm{CO} ; 2$.

Kirby, E., K. X. Whipple, B. C. Burchfiel, W. Q. Tang, G. Berger, Z. M. Sun, and Z. L. Chen (2000), Neotectonics of the Min Shan, China: Implications for mechanisms driving Quaternary deformation along the eastern margin of the Tibetan Plateau, Geol. Soc. Am. Bull., 112, 375-393, doi:10.1130/00167606(2000)112<0375:NOTMSC $>2.3$.CO 2 .

Kirby, E., P. W. Reiners, M. A. Krol, K. X. Whipple, K. V. Hodges, K. A. Farley, W. Tang, and Z. Chen (2002), Late Cenozoic evolution of the eastern margin of the Tibetan Plateau:Inferences from ${ }^{40} \mathrm{Ar} /{ }^{39} \mathrm{Ar}$ and $(\mathrm{U}-\mathrm{Th}) / \mathrm{He}$ thermochronology, Tectonics, 21(1), 1001, doi:10.1029/2000TC001246.

Kirby, E., K. X. Whipple, W. Tang, and Z. Chen (2003), Distribution of active rock uplift along the eastern margin of the Tibetan Plateau: Inferences from bedrock channel longitudinal profiles, J. Geophys. Res., 108(B4), 2217, doi:10.1029/ 2001JB000861

Kirstein, L. A., H. Sinclair, F. M. Stuart, and K. Dobson (2006), Rapid early Miocene exhumation of the Ladakh batholith, western Himalaya, Geology, 34 1049-1052, doi:10.1130/G22857A.1.

Kraml, M., R. Pik, M. Rahn, R. Selbekk, J. Carignan, and J. Keller (2006), A new multi-mineral age reference material for ${ }^{40} \mathrm{Ar} /{ }^{39} \mathrm{Ar}$, (U-Th)/He and fission track dating methods: The Limberg $\mathrm{t} 3$ Tuff, Geostand. Geoanal. Res., 30, 73 -86, doi:10.1111/ j.1751-908X.2006.tb00914.X.

Lal, D., N. B. W. Harris, K. K. Sharma, Z. Gu, L. Ding, T. Liu, W. Dong, M. W. Caffee, and A. J. T. Jull (2004), Erosion history of the Tibetan Plateau since the last interglacial: Constraints from the first studies of cosmogenic ${ }^{10} \mathrm{Be}$ from Tibetan bedrock, Earth Planet. Sci. Lett., 217, 33-42, doi:10.1016/ S0012-821X(03)00600-9.

Lavé, J., and J.-P. Avouac (2001), Fluvial incision and tectonic uplift across the Himalayas of central Nepal, J. Geophys. Res., 106, 26,561-26,591, doi:10.1029/2001JB000359.

Lin, A., Z. Ren, D. Jia, and X. Wu (2009), Co-seismic thrusting rupture and slip distribution produced by the $2008 \mathrm{Mw} 7.9$ Wenchuan earthquake, China, Tectonophysics, 471, 203-215, doi:10.1016/j.tecto.2009.02.014

Liu-Zeng, J., P. Tapponnier, Y. Gaudemer, and L. Ding (2008), Quantifying landscape differences across the Tibetan Plateau: Implications for topographic relief evolution, J. Geophys. Res., 113, F04018, doi:10.1029/2007JF000897.

Mattauer, M., J. Malavieille, S. Calassou, J. Lancelot, F. Roger, Z. W. Hao, Z. Q. Xu, and L. W. Hou (1992), The Songpan-Garze Triassic belt of west Sechuan 
and eastern Tibet: A décollement fold belt on passive margin, C. R. Acad. Sci., 314, 619-626.

Meng, Q. R., J. M. Hu, E. Wang, and H. J. Qu (2006), Late Cenozoic denudation by large-magnitude landslides in the eastern edge of Tibetan Plateau, Earth Planet. Sci. Lett., 243, 252-267, doi:10.1016 j.epsl.2005.12.008

New, M., D. Lister, M. Hulme, and I. Makin (2002), A high-resolution data set of surface climate over global land areas, Clim. Res., 21, 1-25, doi:10.3354/ cr021001.

Pik, R. B. Marty, J. Carignan, and J. Lave (2003), Stability of the Upper Nile drainage network (Ethiopia) deduced from (U-Th)/He thermochronometry: Implications for uplift and erosion of the Afar plume dome, Earth Planet. Sci. Lett., 215 , 73 -88, doi:10.1016/S0012-821X(03)00457-6.

Reiners, P. W. (2005), Zircons (U-Th)/He thermochrometry, in Low-Temperature Thermochronology: Techniques, Interpretations, and Applications, Rev Mineral. Geochem., vol. 58, edited by P. W. Reiners and T. A. Ehlers, pp. 151-179, Mineral. Soc. of Am., Chantilly, Va., doi:10.2138/rmg.2005.58.6.

Reiners, P. W., and M. T. Brandon (2006), Using thermochronology to understand orogenic erosion, Annu. Rev. Earth Planet. Sci., 34, 419-466, doi:10.1146/annurev.earth.34.031405.125202

Reiners, P. W., T. L. Spell, S. Nicolescu, and K. A Zanetti (2004), Zircon (U-Th)/He thermochronometry: He diffusion and comparisons with ${ }^{40} \mathrm{Ar}-{ }^{39} \mathrm{Ar}$ dating, Geochim. Cosmochim. Acta, 68, 18571887, doi:10.1016/j.gca.2003.10.021

Replumaz, A., and P. Tapponnier (2003), Reconstruction of the deformed collision zone between India and Asia by backward motion of lithospheric blocks, J. Geophys. Res., 108(B6), 2285, doi:10.1029/2001JB000661.

Richardson, N. J., A. L. Densmore, D. Seward, A. Fowler, A. Wipf, M. A. Ellis, L. Yong, and Y Zhang (2008), Extraordinary denudation in the Sichuan Basin: Insights from low-temperature ther- mochronology adjacent to the eastern margin of the Tibetan Plateau, J. Geophys, Res., 113 , B04409, doi:10.1029/2006JB004739.

Roger, F., J. Malavieille, P. H. Leloup, S. Calassou, and $\mathrm{Z} . \mathrm{Xu}$ (2004), Timing of granite emplacement and cooling in the Songpan-Garze fold belt (eastern Tibetan Plateau) with tectonic implications, J. Asian Earth Sci., 22, 465-481, doi:10.1016/S13679120(03)00089-0.

Royden, L. H., B. C. Burchfiel, R. W. King, E. Wang, Z. L. Chen, F. Shen, and Y. P. Liu (1997), Surface deformation and lower crustal flow in eastern Tibet, Science, 276, 788-790, doi:10.1126/science. 276 . 5313.788 .

Shuster, D. L., R. M. Flowers, and K. A. Farley (2006), The influence of natural radiation damage on helium diffusion kinetics in apatite, Earth Planet. $\mathrm{Sc}$ Lett., 249, 148-161, doi:10.1016/j.eps1.2006. 07.028 .

Tapponnier, P., Z. Q. Xu, F. Roger, B. Meyer, N. Arnaud, G. Wittlinger, and J. S. Yang (2001), Oblique stepwise rise and growth of the Tibet Plateau, Science, 294, 1671-1677, doi:10.1126/science.105978.

Wang, X., J. Wang, Q. Li, and H. Yu (2000), Deep heat flow and geothermal structure in Sichuan Basin of China, paper presented at World Geothermal Congress, Int. Geotherm. Assoc., Tokyo.

Whipp, D. M., T. A. Ehlers, A. E. Blythe, K. W Huntington, K. V. Hodges, and D. W. Burbank (2007), Plio-Quaternary exhumation history of the central Nepalese Himalaya: 2. Thermokinematic and thermochronometer age prediction model, Tectonics, 26, TC3003, doi:10.1029 2006TC001991.

Wilson, C. J. L., M. J. Harrowfield, and A. J. Reid (2006), Brittle modification of Triassic architecture in eastern Tibet: Implications for the construction of the Cenozoic Plateau, J. Asian Earth Sci., 27, $341-$ 357, doi:10.1016/j.jseaes.2005.04.004

Wolf, R. A., K. A. Farley, and D. M. Kass (1998), Modeling the temperature sensitivity of the apatite
(U-Th)/He thermochronometer, Chem. Geol., 148, 105-114, doi:10.1016/S0009-2541(98)00024-2.

Worley, B. A., and C. J. L. Wilson (1996), Deformation partitioning and foliation reactivation during transpressional orogenesis, an example from the central Longmen Shan, China, J. Struct. Geol., 18, 395 411, doi:10.1016/0191-8141(95)00095-U.

Xu, G. Q., and P. J. J. Kamp (2000), Tectonics and denudation adjacent to the Xianshuihe Fault, eastern Tibetan Plateau: Constraints from fission track thermochronology, J. Geophys. Res., 105, 19,23119,251, doi:10.1029/2000JB900159.

Zhou, M. F., D. P. Yan, C. L. Wang, L. Qi, and A Kennedy (2006), Subduction-related origin of the 750 Ma Xuelongbao adakitic complex (Sichuan Province, China): Implications for the tectonic setting of the giant Neoproterozoic magmatic event in south China, Earth Planet. Sci. Lett., 248, $286-$ 300, doi:10.1016/j.epsl.2006.05.032.

Zhou, X., X. Wang, S. Yang, H. Yu, and Y. Zeng (2000), The analysis of geothermal field characteristics in Sichuan Basin of China, paper presented at World Geothermal Congress, Int Geotherm. Assoc., Tokyo.

R. Cattin, Géosciences Montpellier UMR 5243, Université Montpellier 2, CNRS, Place E. Bataillon, F-34095 Montpellier CEDEX 5, France.

J. de Sigoyer and M. Pubellier, ENS, Laboratoire de Géologie, 24 rue Lhomond, F-75231 Paris CEDEX 05, France.

V. Godard, CEREGE, Europôle Méditerranen de l'Arbois, B.P. 80, F-13545 Aix-en-Provence CEDEX 4 France. (godard@cerege.fr)

J. Lavé, R. Pik, and B. Tibari, CRPG, UPR 2300 , Nancy Université, CNRS, 15 rue ND des pauvres, B.P. 20, F-54501 Vandoeuvre-Lès-Nancy, France.

J. Zhu, Chengdu University of Technology, Chengdu, 